\title{
Article \\ Characterization of the Role of Extracellular Vesicles Released from Chicken Tracheal Cells in the Antiviral Responses against Avian Influenza Virus
}

\author{
Kelsey O'Dowd ${ }^{1,2}$, Laura Sánchez ${ }^{2}$, Jennifer Ben Salem ${ }^{3,4}$, Francis Beaudry ${ }^{3,4}$ and Neda Barjesteh ${ }^{1,2, * *(1)}$ \\ 1 Research Group on Infectious Diseases in Production Animals (GREMIP), \\ Department of Pathology and Microbiology, Faculty of Veterinary Medicine, Université de Montréal, \\ Saint-Hyacinthe, QC J2S 2M2, Canada; kelsey.odowd@umontreal.ca \\ 2 Swine and Poultry Infectious Disease Research Center (CRIPA), Faculty of Veterinary Medicine, \\ Université de Montréal, Saint-Hyacinthe, QC J2S 2M2, Canada; Laura.sanchez@umontreal.ca \\ 3 Animal Pharmacology Research Group of Quebec (GREPAQ), Department of Veterinary Medicine, \\ Faculty of Veterinary Medicine, Université de Montréal, Saint-Hyacinthe, QC J2S 2M2, Canada; \\ jennifer.ben.salem@umontreal.ca (J.B.S.); francis.beaudry@umontreal.ca (F.B.) \\ 4 Centre de Recherche sur le Cerveau et L'apprentissage (CIRCA), Université de Montréal, \\ Montreal, QC J2S 2M2, Canada \\ * Correspondence: neda.barjesteh@umontreal.ca
}

check for updates

Citation: O’Dowd, K.; Sánchez, L.; Ben Salem, J.; Beaudry, F.; Barjesteh, N. Characterization of the Role of Extracellular Vesicles Released from Chicken Tracheal Cells in the Antiviral Responses against Avian Influenza Virus. Membranes 2022, 12, 53. https://doi.org/10.3390/ membranes12010053

Academic Editor: Tak-Wah Wong

Received: 2 December 2021

Accepted: 26 December 2021

Published: 31 December 2021

Publisher's Note: MDPI stays neutral with regard to jurisdictional claims in published maps and institutional affiliations.

Copyright: (C) 2021 by the authors. Licensee MDPI, Basel, Switzerland. This article is an open access article distributed under the terms and conditions of the Creative Commons Attribution (CC BY) license (https:// creativecommons.org/licenses/by/ $4.0 /)$.

\begin{abstract}
During viral respiratory infections, the innate antiviral response engages a complex network of cells and coordinates the secretion of key antiviral factors, such as cytokines, which requires high levels of regulation and communication. Extracellular vesicles (EVs) are particles released from cells that contain an array of biomolecules, including lipids, proteins, and RNAs. The contents of EVs can be influenced by viral infections and may play a role in the regulation of antiviral responses. We hypothesized that the contents of EVs released from chicken tracheal cells are influenced by viral infection and that these EVs regulate the function of other immune cells, such as macrophages. To this end, we characterized the protein profile of EVs during avian influenza virus (AIV) infection and evaluated the impact of EV stimulation on chicken macrophage functions. A total of 140 differentially expressed proteins were identified upon stimulation with various stimuli. These proteins were shown to be involved in immune responses and cell signaling pathways. In addition, we demonstrated that EVs can activate macrophages. These results suggest that EVs play a role in the induction and modulation of antiviral responses during viral respiratory infections in chickens.
\end{abstract}

Keywords: chicken; proteomics; antiviral responses; avian influenza virus; extracellular vesicles; chicken tracheal cells; macrophages

\section{Introduction}

During viral respiratory infections, host innate responses aim to prevent viral entry and replication through a variety of strategies, which collectively act as the first line of defense prior to the induction of adaptive immune responses. Upon the infection with avian viral respiratory pathogens, such as avian influenza virus (AIV), epithelial cells become the primary target of the virus [1-3]. Innate antiviral responses involve a complex network of cells, including macrophages and dendritic cells, which can engage cell sensors, such as pattern recognition receptors (PRRs), that detect viral components and activate specific signaling pathways. Furthermore, AIV can infect macrophages [2]. Activation of epithelial cells and macrophages following pathogen recognition leads to the recruitment of other cells of the immune system and subsequent production of interferons (IFNs), interleukins (ILs), and other pro-inflammatory cytokines. Moreover, type I IFNs, IFN- $\alpha$ and IFN- $\beta$, induce an antiviral state in virus-infected cells and in neighboring cells by initiating the production of IFN-stimulated genes (ISGs), which can interfere with the viral replication 
cycle and contribute to pathogen clearance [2-4]. In addition, macrophages have other functions essential for host defense against pathogens, such as phagocytosis, secretion of antimicrobial peptides, and antigen presentation [5].

Given the complex and highly regulated immune responses and the extensive hostpathogen interactions involved during infection, regulated communication and coordination between host cells are essential for efficient detection, regulation, and clearance of invading pathogens. This communication can be through the production of cytokines, direct cell-to-cell contact, or the secretion of extracellular vesicles (EVs) [6]. EVs are a heterogenous group of lipid-encapsulated particles released by all cell types and measuring 30-1000 nm [7]. Several subcategories of EVs, such as exosomes, microvesicles, and apoptotic bodies, are characterized based on biogenesis pathways, size, and specific protein markers [8,9]. Following secretion, EVs can be taken up through several mechanisms, including endocytosis, phagocytosis, or membrane fusion [10]. These particles contain a diverse cargo of biomolecules, including lipids, proteins, and ribonucleic acids (RNAs), such as microribonucleic acids (miRNAs), which can play a role in information transfer and act as a cellular "language" $[8,11,12]$. These regulators of gene expression have been shown to regulate several biological processes, including immune responses, which makes them key molecules of interest for EV profiling studies [13]. In addition, several studies have shown that viral infections can affect EV contents and influence information transfer and resulting immune responses [14-18].

The contents and specific regulatory roles of EVs are poorly described in the context of infectious diseases in chickens. The few studies that have characterized the contents of EVs in the context of immune responses in chickens focus primarily on miRNA profiles, with little focus on protein content; therefore, studies are required to evaluate the role of EV protein content in the induction and modulation in the host response to viral infections [1926]. For example, a recent study evaluated the proteomic profile of serum exosomes from Marek's Disease Virus (MDV)-vaccinated and protected and lymphoma-bearing chickens and identified potential biomarkers for the disease [24]. The characterization of EV proteomic profiles will allow for a better understanding of EV dynamics and important insight for the development of new strategies for the control of viral infections in chickens using EVs.

Furthermore, studies evaluating the impact of EV stimulation on immune cell functions in chickens are rare. In macrophages specifically, there are two studies assessing the impact of stimulating chicken macrophages with macrophage-derived exosomes stimulated with either polyinosinic: polycytidylic acid (polyI:C) or lipopolysaccharide (LPS). These studies revealed that these exosomes can modulate the immune response through specific antiviral pathways, such as the NF- $\mathrm{kB}$ signaling pathway $[27,28]$.

We previously described the induction of antiviral responses and communication between tracheal cells and macrophages in the chicken respiratory system [29-32]. Furthermore, we showed that chicken tracheal cells release EVs. Moreover, we found that the miRNA profile of EVs is influenced by the type of stimuli [33]. In this study, we aimed to investigate another component of the EV cargo and characterize the protein content of EVs released from chicken tracheal cells and their functional properties, including their impact on the function of macrophages. We hypothesized that viral infection influences the contents of EVs released from chicken tracheal cells and that these EVs regulate the function of other immune cells, such as macrophages. Ultimately, we characterized the protein profile of EVs and evaluated the impact of EVs on cells of the immune system in the context of antiviral responses against avian influenza virus infection.

\section{Material and Methods}

\subsection{Avian Influenza Virus (AIV)}

Ten-day-old specific-pathogen-free (SPF) embryonated chicken eggs (layer chickens, white Leghorn, Canadian Food Inspection Agency, Ottawa, ON, Canada) were used to propagate the low pathogenic avian influenza virus AIV A/Duck/Czech/56 (H4N6) by inoculation through the allantoic cavity [34]. Briefly, the eggs were candled to verify proper 
embryo development and $100 \mu \mathrm{L}$ of stock allantoic fluid containing 0.2 hemagglutinin units (HAU) of the H4N6 virus was injected through the allantoic cavity. The allantoic fluid was harvested from the eggs at $48 \mathrm{~h}$ post-inoculation and the virus titer was determined using endpoint dilution in Madin-Darby Canine Kidney (MDCK) cells (a gracious gift from Dr. Shayan Sharif's laboratory at the Ontario Veterinary College, University of Guelph, ON, Canada) [35].

\subsection{Toll-Like Receptor (TLR) Ligands}

TLR ligands lipopolysaccharide (LPS) from Escherichia coli 026:B6 (Sigma-Aldrich, Oakville, ON, Canada) and polyinosinic:polycytidylic acid (polyI:C) (InvivoGen, San Diego, CA, USA) were used in this study. These TLR ligands were selected because they were previously shown to induce immune responses in chicken tracheal cells [31,32].

\subsection{Tracheal Organ Culture (TOC)}

TOC was performed as previously described [31]. Briefly, tracheas were aseptically collected from nineteen-day-old SPF chicken embryos (Canadian Food Inspection Agency, Ottawa, ON, Canada) and washed twice with warm Hanks' balanced salt solution (HBSS, Gibco, Burlington, ON, Canada) to remove excess mucus. The connective tissues surrounding the trachea were removed by thorough dissection. Tracheas were then manually dissected into $1 \mathrm{~mm}$ rings using razor blades. The rings were transferred into 6-well cell culture plates (one embryo per well, 10-15 rings per embryo) containing phenol redfree complete Medium 199 (Sigma-Aldrich, Oakville, ON, Canada) supplemented with 10\% EV-depleted and heat-inactivated fetal bovine serum (FBS, Gibco, Burlington, ON, Canada), 2 mM GlutaMax supplement (Gibco, Burlington, ON, Canada), 25 mM 4-(2hydroxyethyl)-1-piperazineethanesulfonic acid (HEPES) buffer (Gibco, Burlington, ON, Canada), $100 \mathrm{U} / \mathrm{mL}$ penicillin/100 $\mathrm{gg} / \mathrm{mL}$ streptomycin (Gibco, Burlington, ON, Canada), and $50 \mu \mathrm{g} / \mathrm{mL}$ gentamicin (Gibco, Burlington, ON, Canada). To prepare EV-depleted FBS, FBS was first heat-inactivated at $56{ }^{\circ} \mathrm{C}$ for $30 \mathrm{~min}$ and then complete Medium 199 containing $20 \%$ FBS was ultracentrifuged at $100,000 \times g$ for $18 \mathrm{~h}\left(4^{\circ} \mathrm{C}\right)(38.5 \mathrm{~mL}$, Open-Top Thinwall Ultra-Clear Tube, $25 \times 89 \mathrm{~mm}$ 344,058 and Optima L-100XP, Beckman Coulter, Mississauga, ON, Canada). The supernatant was then collected and filtered through a $0.2 \mu \mathrm{m}$ syringe filter (VWR, Montreal, QC, Canada) and diluted with complete Medium 199 to reach a final concentration of $10 \%$ FBS.

The tracheal rings were incubated at room temperature on a low-speed benchtop rocker for three hours to exclude mucus production and potential reactions from the process of TOC preparation. Following the incubation, the media was replaced with fresh complete Medium 199 containing 10\% FBS. During the experiments, the ciliary activity of the TOC was monitored and confirmed under a light microscope.

\subsection{Chicken Macrophage Cell Line}

The Muquarrab Qureshi-North Carolina State University (MQ-NCSU) cell line, a gracious gift from Dr. Shayan Sharif's laboratory at the Ontario Veterinary College, University of Guelph, ON, Canada, is an avian macrophage cell line derived from spleen cells infected with the JM/102W strain of Marek's disease virus [36]. The MQ-NSCU cells were cultured in LM-HAHN media composed of a 1:1 ratio of McCoy's 5 A (modified) medium (Gibco, Burlington, ON, Canada) and Leibovitz's L-15 medium (Gibco, Burlington, ON, Canada) supplemented with 8\% heat-inactivated FBS (Gibco, Burlington, ON, Canada), 10\% heat-inactivated chicken serum (Gibco, Burlington, ON, Canada), 1\% tryptose phosphate broth (Gibco, Burlington, ON, Canada), 1\% sodium pyruvate (Gibco, Burlington, ON, Canada), 2 mM GlutaMax supplement (Gibco, Burlington, ON, Canada), 100 U/mL penicillin $/ 100 \mu \mathrm{g} / \mathrm{mL}$ streptomycin (Gibco, Burlington, ON, Canada), and $50 \mu \mathrm{g} / \mathrm{mL}$ gentamicin (Gibco, Burlington, ON, Canada) at $40{ }^{\circ} \mathrm{C}$ and $5 \% \mathrm{CO}_{2}$ in a humidified incubator. 


\subsection{Determining Protein Content of EVs Released from TOC}

\subsubsection{TOC Infection with AIV and Stimulation with TLR Ligands}

For AIV infection of TOCs, tracheal rings were infected with $10^{4} \mathrm{pfu} / \mathrm{mL}$. For the TLR ligand stimulation of TOCs, tracheal rings were stimulated with either LPS $(1 \mu \mathrm{g} / \mathrm{mL})$ or polyI:C $(25 \mu \mathrm{g} / \mathrm{mL})$ (doses were selected based on previous studies in chickens) [29,31,32] TOCs were incubated at $40{ }^{\circ} \mathrm{C}$ and $5 \% \mathrm{CO}_{2}$ in a humidified incubator. Infection/stimulation for all treatment groups was done in complete FBS-free Medium 199 as animal sera contain non-specific inhibitors of influenza viruses [37]. Furthermore, the control groups received complete FBS-free Medium 199. At $2 \mathrm{~h}$ post-stimulation/-infection, tracheal rings were washed twice with HBSS (Gibco, Burlington, ON, Canada) before incubation at $40{ }^{\circ} \mathrm{C}$ and $5 \% \mathrm{CO}_{2}$ in a humidified incubator in fresh complete FBS-free Medium 199.

\subsubsection{EV Isolation}

After a $24 \mathrm{~h}$ incubation period at $40^{\circ} \mathrm{C}$ and $5 \% \mathrm{CO}_{2}$ in a humidified incubator, TOC supernatants were collected. There were two replicates per treatment group; each replicate consisting of supernatants pooled from three wells (three individual embryos). An optimized ultracentrifugation protocol for EV isolation from TOC supernatants was used [33]. Briefly, all the centrifugation and ultracentrifugation was performed at $4{ }^{\circ} \mathrm{C}$. Ultracentrifugation was performed using the $17 \mathrm{~mL}$, Polypropylene Tube, $16 \times 96 \mathrm{~mm}$, and Optima L-100XP (Beckman Coulter, Mississauga, ON, Canada). Supernatants were first centrifuged at $300 \times g$ for $10 \mathrm{~min}$ to remove cellular debris. Supernatants were then recovered and centrifuged at $2000 \times g$ for $20 \mathrm{~min}$. Supernatants were again recovered and ultracentrifuged at $10,000 \times g$ for $30 \mathrm{~min}$. Supernatants were recovered and filtered with $0.2 \mu \mathrm{m}$ syringe filters (VWR, Montreal, QC, Canada), followed by ultracentrifugation at $100,000 \times g$ for $60 \mathrm{~min}$. Supernatants were discarded and pellets were resuspended in FBS-free complete Medium 199 and ultracentrifuged at 100,000 $\times \mathrm{g}$ for a final $60 \mathrm{~min}$. Following the final round of ultracentrifugation, the supernatants were discarded. For samples designated for mass spectrometry (MS) analysis, the pellets were resuspended in $50 \mu \mathrm{L}$ of $50 \mathrm{mM}$ ammonium bicarbonate $(\mathrm{pH}=8)$ (Sigma-Aldrich, Oakville, ON, Canada) and stored at $-80{ }^{\circ} \mathrm{C}$. Samples designated for protein concentration determination and macrophage experiments were resuspended in phosphate-buffered saline (PBS, Gibco, Burlington, ON, Canada). The protein concentrations of the isolated EVs were determined using the Micro BCA Protein Assay Kit according to the manufacturer's instructions (Thermo Fisher Scientific, Burlington, ON, Canada). To validate the purity of the EVs isolated using this protocol, the presence of specific EV protein markers and the morphology of EVs were confirmed by Western Blot and transmission electron microscopy (TEM), respectively, in our previous study [33].

\subsubsection{Sample Preparation for Mass Spectrometry Analysis}

To identify the proteins present in the EV samples by MS, protein digestion was performed using the In-Solution Tryptic Digestion according to the manufacturer instructions (Thermo Fisher Scientific, Burlington, ON, Canada) with some modifications. Briefly, the samples were thawed and an additional $50 \mu \mathrm{L}$ of $50 \mathrm{mM}$ ammonium bicarbonate $(\mathrm{pH}=8.0)$ (Sigma-Aldrich, Oakville, ON, Canada) including a cocktail of proteinase inhibitors (cOmplete, Mini Protease Inhibitor Cocktail, Sigma-Aldrich, Oakville, ON, Canada) was added. Samples were homogenized by bead mill homogenization using reinforced $1.5 \mathrm{~mL}$ homogenizer tubes containing $50 \mathrm{mg}$ glass beads. The samples were homogenized with three bursts of $60 \mathrm{~s}$ at a speed of $5 \mathrm{~m} / \mathrm{s}$. Proteins were precipitated by adding cold acetone at a ratio of $1 / 5(v / v)$. Samples were then centrifuged at $12,000 \times g$ for $10 \mathrm{~min}$, supernatants were discarded, and pellets were resuspended in $50 \mathrm{mM}$ tris hydrochloride (Tris- $\mathrm{HCl}$ ) buffer $(\mathrm{pH}=8.0)$. Denaturation of proteins was done at $95^{\circ} \mathrm{C}$ for $15 \mathrm{~min}$ and allowed to cool. Reduction and alkylation were performed as follows: samples were reduced with $20 \mathrm{mM}$ dithiothreitol (DTT) at $90^{\circ} \mathrm{C}$ for $15 \mathrm{~min}$ and alkylated with $40 \mathrm{mM}$ iodoacetamide (IAA) at room temperature for $30 \mathrm{~min}$ protected from light. The alkylation reaction was 
quenched with the addition of DTT (10 $\mathrm{mM}$ final concentration). Five micrograms of proteomic-grade trypsin was added. The reaction was performed at $37^{\circ} \mathrm{C}$ for $24 \mathrm{~h}$. Finally, the protein digestion was quenched by adding $10 \mu \mathrm{L}$ of a $1 \%$ trifluoroacetic acid (TFA) solution. Samples were centrifuged at $12,000 \times \mathrm{g}$ for $10 \mathrm{~min}$, and the supernatants were transferred into injection vials for analysis.

\subsubsection{Mass Spectrometry-Based Proteomics}

The analyses were carried out on a Vanquish FLEX Ultra High-Performance Liquid Chromatography (UHPLC) system coupled to a Q Exactive Plus Orbitrap Mass Spectrometer (Thermo Scientific, San Jose, CA, USA). HPLC separation was performed using gradient elution with a microbore column Thermo Biobasic C18 $150 \times 1 \mathrm{~mm}$, with a particle size of $5 \mu \mathrm{m}$. The $5 \mu \mathrm{L}$ of sample was separated at a flow rate of $50 \mu \mathrm{L} / \mathrm{min}$ using a gradient elution strategy. The initial mobile phase condition consisted of acetonitrile and water (both fortified with $0.1 \%$ of formic acid) at a ratio of 5:95. From 0 to $3 \mathrm{~min}$, the ratio was maintained at 5:95. From 3 to $123 \mathrm{~min}$, a linear gradient was applied up to a ratio of 40:60 and maintained for $3 \mathrm{~min}$. The mobile phase composition ratio was reverted at the initial conditions and the column was allowed to re-equilibrate for $25 \mathrm{~min}$. The Q Exactive Plus Orbitrap Mass Spectrometer was interfaced with the UHPLC system using a pneumatic assisted heated electrospray ion source. Nitrogen was used for sheath and auxiliary gases and was set at 10 and 5 arbitrary units. Auxiliary gas was heated to $200{ }^{\circ} \mathrm{C}$. The heated electrospray ionization (ESI) probe was set to $4000 \mathrm{~V}$ and the ion transfer tube temperature was set to $300^{\circ} \mathrm{C}$. MS detection was performed in positive ion mode and operating in TOP10 Data Dependent Acquisition (DDA). A DDA cycle entailed one $\mathrm{MS}^{1}$ survey scan $(\mathrm{m} / \mathrm{z}$ 400-1500) acquired at 70,000 resolution (FWHM) and precursors ions meeting user-defined criteria for charge state (i.e., $z=2,3$, or 4 ), monoisotopic precursor intensity (dynamic acquisition of MS ${ }^{2}$ based TOP-10 most intense ions with a minimum $1 \times 10^{4}$ intensity threshold). Precursor ions were isolated using the quadrupole (1.5 Da isolation width) and activated by HCD ( $28 \mathrm{NCE})$, and fragment ions were detected in the Orbitrap at 17,500 resolution (FWHM). Datasets were analyzed using Thermo Proteome Discoverer (version 2.4) in combination with SEQUEST using default settings unless otherwise specified. SEQUEST used a curated database consisting of FASTA sequences extracted from UniProt (Gallus reference proteome, proteome identifier UP000000539). Parameters were set as follows: $\mathrm{MS}^{1}$ tolerance of $10 \mathrm{ppm}$; $\mathrm{MS}^{2}$ mass tolerance of $0.02 \mathrm{Da}$ for Orbitrap detection; enzyme specificity was set as trypsin with two missed cleavages allowed; carbamidomethylation of cysteine was set as a fixed modification; and oxidation of methionine was set as a variable modification. The minimum peptide length was set to six amino acids, and proteins identified by only one peptide were removed. Datasets were further analyzed with Percolator to improve the rate of confident peptide identifications [38]. Peptide-spectrum-matches (PSMs) and protein identification were filtered at $1 \%$ false discovery rate (FDR) threshold. For protein quantification and comparative analysis, we used the peak integration feature of the Proteome Discoverer 2.4 software [39]. For each identified protein, the average ion intensity of unique peptides was used for protein abundance.

\subsubsection{Protein Functional Analyses}

The abundance ratios were generated from (Sample)/(Control) abundance values. Volcano plots were generated for proteins that had an associated abundance ratio and $p$ value (Benjamini-Hochberg method). Proteins with an abundance ratio $\geq 2$-fold change and a $p$-value $<0.05$ were considered differentially expressed (DE) and retained for downstream analysis. The databases ExoCarto (http://www.exocarta.org/; accessed date: 16 August 2021) and Vesiclepedia (http:/ / microvesicles.org/index.html\#; accessed date: 16 August 2021) were used to screen for exosome-associated proteins [40,41]. Venn diagram analysis for the DE proteins among the different treatment groups was performed using the online tool http:/ / bioinformatics.pbs.ugent.be/webtools/Venn/ (accessed date: 17 November 2020). Functional annotation of the DE proteins was performed by gene 
ontology (GO) mapping using PANTHER (Protein Analysis Through Evolutionary Relationships Classification System, http:/ / pantherdb.org/; accessed date: 19 August 2021) [42]. In addition, the associated pathways extracted from the PANTHER database were used to create tables and networks, which were then imported into Cytoscape to generate diagrams representing these networks [43]. Furthermore, the STRING database (Search Tool for the Retrieval of Interacting Genes/Proteins, https://string-db.org/; accessed date: 20 December 2021) was used to assess and illustrate relationships among the DE proteins (medium confidence score of 0.400) [44].

\subsection{Treatment of Chicken Macrophages with EVs Released from TOC \\ 2.6.1. EV Uptake by Chicken Macrophages}

MQ-NCSU cells were seeded in 24-well plates in DMEM cell culture media composed of Dulbecco's Modified Eagle Medium (DMEM, Gibco, Burlington, ON, Canada) supplemented with 10\% FBS (Gibco, Burlington, ON, Canada), 2 mM GlutaMax Supplement (Gibco, Burlington, ON, Canada), $100 \mathrm{U} / \mathrm{mL}$ penicillin $/ 100 \mu \mathrm{g} / \mathrm{mL}$ streptomycin (Gibco, Burlington, ON, Canada), and $50 \mu \mathrm{g} / \mathrm{mL}$ gentamicin (Gibco, Burlington, ON, Canada) at a cell density of $5 \times 10^{4}$ cells/well and incubated at $40{ }^{\circ} \mathrm{C}$ and $5 \% \mathrm{CO}_{2}$ in a humidified incubator overnight. The cells were then labeled with PKH67 Green Fluorescent Cell Linker Kit for General Cell Membrane Labeling (Sigma-Aldrich, Oakville, ON, Canada) according to the manufacturer's instructions with modifications. Briefly, $4 \mu \mathrm{L}$ of PKH67 dye was added to $1 \mathrm{~mL}$ of Diluent $C$ and $100 \mu \mathrm{L}$ of the solution was added to each well. Following a 5 -min incubation period at room temperature, $100 \mu \mathrm{L}$ of $1 \%$ BSA (Gibco, Burlington, ON, Canada) was added to each well for $1 \mathrm{~min}$. Finally, cells were washed three times with PBS. Unlabeled macrophage controls were also included. EVs isolated from TOC were labeled with PKH26 Red Fluorescent Cell Linker Kit for General Cell Membrane Labeling (Sigma-Aldrich, Oakville, ON, Canada) according to the manufacturer's instructions with some modifications, as previously described [45]. Briefly, the EVs were added to $1 \mathrm{~mL}$ Diluent $\mathrm{C}$, and $4 \mu \mathrm{L}$ of PKH26 dye was added to $1 \mathrm{~mL}$ Diluent $\mathrm{C}$. The EVs and dye were mixed and incubated at room temperature for $5 \mathrm{~min}$ before $2 \mathrm{~mL}$ of $1 \%$ BSA (Gibco, Burlington, ON, Canada) was added. PBS-PKH26 controls were included. Using Amicon Ultra-4 Centrifugal Filter Unit Ultracel $100 \mathrm{k}$ (MilliporeSigma, Burlington, MA, USA), the samples were centrifuged at $4000 \times g$ and then washed three times with PBS, before being washed twice with DMEM (Gibco, Burlington, ON, Canada). Following the labeling and incubation, MQ-NCSU cells were treated with $10 \mu \mathrm{g}$ labeled EVs per well and incubated for $2 \mathrm{~h}$. Untreated PKH67-labelled macrophage controls were included. Cells were then washed twice with PBS (Gibco, Burlington, ON, Canada) and fixed in 4\% formalin (SigmaAldrich, Oakville, ON, Canada) for $15 \mathrm{~min}$ at room temperature. Finally, cells were washed twice with PBS (Gibco, Burlington, ON, Canada). EV uptake by macrophages was then visualized using a Leica DMI 4000B automated inverted fluorescence microscope with a Leica DFC 490 digital camera and the Leica Application Suite Software, version 3.8.0 (Leica Microsystems Inc., Richmond Hill, ON, Canada). Fiji/ImageJ software and the stitching plugin were used for image analysis [46,47].

\subsubsection{Nitric Oxide (NO) Production by Chicken Macrophages Treated with EVs}

MQ-NCSU cells were seeded in 48-well plates at a viable cell density of $5 \times 10^{5}$ cells/well in DMEM cell culture media at $40{ }^{\circ} \mathrm{C}$ and $5 \% \mathrm{CO}_{2}$ in a humidified incubator for $2 \mathrm{~h}$. The cells were then stimulated with two different doses of EVs isolated from TOC: low $(5 \mu \mathrm{g} / \mathrm{mL})$ and high $(50 \mu \mathrm{g} / \mathrm{mL})$. Furthermore, for LPS-stimulated treatment groups, cells were stimulated with $1 \mu \mathrm{g} / \mathrm{mL}$ LPS at $1 \mathrm{~h}$ post-stimulation with EVs. Untreated and LPS-stimulated macrophage controls were included. The ability of EVs to stimulate nitric oxide production in culture supernatants collected $48 \mathrm{~h}$ post-stimulation was evaluated by the Griess assay method. Briefly, $50 \mu \mathrm{L}$ of sulfanilamide solution ( $1 \%$ sulfanilamide and $5 \%$ phosphoric acid in water) (sulfanilamide, Thermo Fisher Scientific, Burlington, ON, Canada) and phosphoric acid, Sigma-Aldrich, Oakville, ON, Canada) were added to 
$50 \mu \mathrm{L}$ of samples in wells of a microplate and incubated for $10 \mathrm{~min}$ at room temperature, protected from light. Next, $50 \mu \mathrm{L}$ of NED solution $(0.1 \% \mathrm{~N}-1$-napthylethylenediamine dihydrochloride in water) (N-(1-Naphthyl)-ethylenediamine dihydrochloride, Bio Basic, Markham, ON, Canada) was added to each well and the plate was then incubated for $10 \mathrm{~min}$ at room temperature, protected from light. Finally, absorbance was measured using a plate reader with a $540 \mathrm{~nm}$ filter. A nitrite standard (sodium nitrite, Bio Basic, Markham, ON, Canada) with a linear range of $0-100 \mu \mathrm{M}$ was included to generate a reference curve.

\subsubsection{Phagocytosis by Chicken Macrophages Treated with EVs}

MQ-NCSU cells were seeded in 96-well Black Polystyrene Microplates (Corning, NY, USA) at a viable cell density of $7.5 \times 10^{4}$ cells/well in DMEM cell culture media and incubated at $40{ }^{\circ} \mathrm{C}$ and $5 \% \mathrm{CO}_{2}$ in a humidified incubator for $2 \mathrm{~h}$. The cells were then stimulated with two different doses of EVs isolated from TOC: low $(5 \mu \mathrm{g} / \mathrm{mL})$ and high $(25 \mu \mathrm{g} / \mathrm{mL})$ and incubated at $40{ }^{\circ} \mathrm{C}$ and $5 \% \mathrm{CO}_{2}$ in a humidified incubator. At $12 \mathrm{~h}$ post-stimulation with EVs, phagocytosis was assessed using pHrodo Red Escherichia coli Bioparticles Conjugates for Phagocytosis (Invitrogen, Burlington, ON, Canada) according to the manufacturer's instructions, with some modifications. Briefly, pHrodo Red Escherichia coli Bioparticles Conjugates were resuspended in $2 \mathrm{~mL}$ Live Cell Imaging Solution (Invitrogen, Burlington, ON, Canada) and sonicated to homogeneously disperse the particles. For each well, $25 \mu \mathrm{L}$ of the medium was removed and replaced with $25 \mu \mathrm{L}$ of resuspended beads. Untreated macrophage controls were included. The samples were then incubated at $37^{\circ} \mathrm{C}$ for $4 \mathrm{~h}$. Finally, fluorescence was evaluated using a fluorescence plate reader at an excitation/emission spectra of 560/586 nm.

\subsubsection{Gene Expression of Chicken Macrophages Treated with EVs}

MQ-NCSU cells were seeded in 48-well plates at a viable cell density of $5 \times 10^{5}$ cells/well in DMEM cell culture media at $40{ }^{\circ} \mathrm{C}$ and $5 \% \mathrm{CO}_{2}$ in a humidified incubator for $2 \mathrm{~h}$. The cells were then stimulated with two different doses of EVs isolated from TOC: low $(5 \mu \mathrm{g} / \mathrm{mL})$ and high $(25 \mu \mathrm{g} / \mathrm{mL})$. Untreated macrophage controls were included. At $3 \mathrm{~h}$ or $18 \mathrm{~h}$ post-stimulation with EVs, cells were collected in TRIzol reagent (Invitrogen, Burlington, ON, Canada) and total RNA was extracted according to the manufacturer's instructions. Total RNA was treated with the DNA-free DNase Kit (Ambion, Austin, TX, USA) according to manufacturer's instructions. For each sample, complementary DNA (cDNA) synthesis was performed with $1 \mu \mathrm{g}$ of RNA using the Maxima Reverse Transcriptase kit (Thermo Scientific, Burlington, ON, Canada) according to the manufacturer instructions and using Oligo $(\mathrm{dT})_{20}$ primer (Invitrogen, Burlington, ON, Canada), dNTP Mix (Thermo Scientific, Burlington, ON, Canada), and RNAseOUT (Invitrogen, Burlington, ON, Canada). Quantitative real-time polymerase chain reaction (RT-PCR) was carried out with cDNA diluted 1:10 in DEPC-treated water and PowerUp SYBR Green Master Mix (Thermo Scientific, Burlington, ON, Canada) according to the manufacturer instructions using the ViiA 7 Real-Time PCR system (Applied Biosystems, Waltham, MA, USA), as previously described [29,30,32]. Briefly, the cycling program consisted of $50{ }^{\circ} \mathrm{C}$ for $2 \mathrm{~min}$, $95^{\circ} \mathrm{C}$ for $10 \mathrm{~min}$, following by 45 cycles of $95^{\circ} \mathrm{C}$ for $10 \mathrm{~s}, 60^{\circ} \mathrm{C}$ or $64^{\circ} \mathrm{C}$ annealing for $5 \mathrm{~s}$, depending on the specific primer (Table 1), and elongation and signal acquisition at $72{ }^{\circ} \mathrm{C}$ for $10 \mathrm{~s}$. Melting curve analysis was done in three steps: $95^{\circ} \mathrm{C}$ for $15 \mathrm{~s}$, cooling to $60{ }^{\circ} \mathrm{C}$ for $1 \mathrm{~min}$, and heating to $95^{\circ} \mathrm{C}$ for $15 \mathrm{~s}$. Finally, data analysis to calculate the relative gene expression was done using the Pfaffl method [48].

\subsection{Statistical Analysis}

Statistical analysis of the NO production and phagocytosis by chicken macrophages treated with EVs data was performed by one-way ANOVA followed by the Tukey test for multiple comparisons. Statistical analysis of the gene expression of chicken macrophages treated with EVs data was performed by student's t-test (two groups). For all statistical 
analyses, calculations were performed using GraphPad Prism software version 9.2.0 (La Jolla, CA, USA) and $p$-value $<0.05$ was considered statistically significant.

Table 1. Primer sequences used for RT-PCR.

\begin{tabular}{|c|c|c|c|}
\hline Target Gene & Primer Sequence & Annealing Temperature $\left({ }^{\circ} \mathrm{C}\right)$ & Reference \\
\hline$\beta$-actin & $\begin{array}{l}\text { F: 5'-CAACACAGTGCTGTCTGGTGGTA-3' } \\
\text { R: 5'-ATCGTACTCCTGCTTGCTGATCC-3' }\end{array}$ & 60 & [49] \\
\hline IFN- $\alpha$ & $\begin{array}{l}\text { F: 5'-ATCCTGCTGCTCACGCTCCTTCT-3' } \\
\text { R: 5'-GGTGTTGCTGGTGTCCAGGATG-3' }\end{array}$ & 64 & [49] \\
\hline IFN- $\beta$ & $\begin{array}{l}\text { F: 5'-GCCTCCAGCTCCTTCAGAATAC G-3' } \\
\text { R: 5'-CTGGATCTGGTTGAGGAGGCTGT-3' }\end{array}$ & 64 & {$[50]$} \\
\hline IL-1 $\beta$ & $\begin{array}{l}\text { F: 5'-GTGAGGCTCAACATTGCGCTGTA-3' } \\
\text { R: 5'-TGTCCAGGCGGTAGAAGATGAAG-3' }\end{array}$ & 64 & [49] \\
\hline MDA5 & $\begin{array}{l}\text { F: 5'-TGGTACAGGCGTTGGTAAGAG-3' } \\
\text { R: 5'-GAGCACATCCGCAGGTAGAG-3' }\end{array}$ & 60 & [30] \\
\hline PKR & $\begin{array}{l}\text { F: 5'-GCAAAACCAGCACTGAATGGG-3' } \\
\text { R: } 5^{\prime} \text {-CGTAAATGCTGTTCCACTAACGG-3' }\end{array}$ & 60 & [30] \\
\hline
\end{tabular}

\section{Results}

3.1. EVs Released from TOCs Treated with AIV, LPS, and PolyI:C Have Distinctive Protein Profiles

The protein profiles were evaluated to determine the ability of AIV infection and LPS and polyI:C stimulation to influence the protein contents of EVs. A total of 140 known DE proteins were identified among all treatment groups, with 52 up-regulated and 88 downregulated proteins (Tables 2 and 3). Using the associated gene symbols, we then referred to the vesicle proteome databases ExoCarta and Vesiclepedia, which contain records of proteins previously shown to be EV-associated [40,41]. Among the DE proteins, 59 were identified in the Vesiclepedia database only, whereas 52 were found in both the ExoCarta and Vesiclepedia databases, for a total of 111 , representing just under $80 \%$ of our identified proteins (Table S1). In addition, 29 proteins not previously found in EVs were identified. It is also important to note that no AIV proteins were found within EVs from our AIV treatment group. Furthermore, the EV protein marker Homo sapiens Tumor susceptibility gene 101 (TSG101) was identified in the EVs [9]. Among the AIV, LPS, and polyI:C treatment groups, a total of 67,85 , and 76 DE proteins were identified, respectively. Proteins were considered DE if they satisfied the $p$-value $<0.05$ and abundance ratio $\geq 2$-fold change threshold conditions. Furthermore, 31, 31, and 24 proteins were up-regulated, whereas 36, 54, and 52 proteins were down-regulated in the AIV, LPS, and polyI:C treatment groups, respectively (Figure 1). Several of the proteins identified in the treated groups were found in more than one treatment group (Figure 2 and Table S2). In all treatment groups, 12 common proteins were up-regulated, and 17 common proteins were down-regulated. In addition, within the AIV, LPS, and polyI:C groups, 9, 17, and 4 proteins were uniquely up-regulated, and 9,22 , and 20 proteins were uniquely down-regulated, respectively. Furthermore, four proteins presented different expression patterns among the different treatment groups. The protein EXOC5 (F1NF87) was up-regulated in the LPS group, but down-regulated in the AIV group. The COL1A2 (A0A5H1ZRJ7) was up-regulated in the LPS group, but down-regulated in the polyI:C group. The GPD2 (F1NCA2) was up-regulated in the LPS group, but down-regulated in the polyI:C group. The LOC107055115 (A0A1D5P3H2) was up-regulated in the polyI:C group, but down-regulated in the AIV group. 
Table 2. Up-regulated proteins of EVs from TOCs treated with AIV, LPS, and polyI:C. Following differential expression filtering (abundance ratio $\geq 2$-fold change and $p$-value $<0.05), 31,31$, and 24 proteins were found to be up-regulated in the AIV, LPS, and polyI:C treatment groups, respectively.

\begin{tabular}{|c|c|c|c|c|c|c|}
\hline Treatment Group & Accession & Protein Name & Gene Symbol & Abundance Ratio & $\log _{2}$ Abundance Ratio & $p$-Value \\
\hline \multirow{27}{*}{$\begin{array}{c}\text { AIV } \\
\text { (31 proteins) }\end{array}$} & A0A1D5PJC0 & Uncharacterized protein & - & 100.00 & 6.64 & $4.57 \times 10^{-3}$ \\
\hline & A0A3Q2TWB1 & Phosphoinositide 5-phosphatase & INPP5B & 77.51 & 6.28 & $5.62 \times 10^{-5}$ \\
\hline & A0A1D5P5K6 & PHD-type domain-containing protein & TCF20 & 32.00 & 5.00 & $2.39 \times 10^{-7}$ \\
\hline & E1BU50 & Uncharacterized protein & LOC419409 & 24.96 & 4.64 & $1.52 \times 10^{-2}$ \\
\hline & A0A1D5P4T1 & Uncharacterized protein & SYTL2 & 20.43 & 4.35 & $7.06 \times 10^{-6}$ \\
\hline & A0A3Q2UIP4 & AT-rich interactive domain-containing protein $5 \mathrm{~B}$ & ARID5B & 14.84 & 3.89 & $1.36 \times 10^{-4}$ \\
\hline & E1BQH9 & Uncharacterized protein & UGGT2 & 14.84 & 3.89 & $2.92 \times 10^{-2}$ \\
\hline & A0A1D5P8Q3 & Uncharacterized protein & PAPLN & 12.78 & 3.68 & $1.42 \times 10^{-2}$ \\
\hline & A0A1D5PVH7 & Tyrosine-protein kinase receptor & IGF1R & 9.73 & 3.28 & $2.14 \times 10^{-2}$ \\
\hline & F1NZ61 & ZnMc domain-containing protein & MMP27 & 9.59 & 3.26 & $5.12 \times 10^{-7}$ \\
\hline & A0A1L1RVC2 & hSH3 domain-containing protein & C8H1orf168 & 9.47 & 3.24 & $1.37 \times 10^{-2}$ \\
\hline & E1BSS2 & Ubiquitin specific peptidase 53 & USP53 & 9.46 & 3.24 & $2.00 \times 10^{-2}$ \\
\hline & A0A1L1RJ96 & FSA_C domain-containing protein & KIAA1109 & 8.67 & 3.12 & $2.45 \times 10^{-2}$ \\
\hline & A0A3Q2UBZ4 & Uncharacterized protein & MSLNL & 8.18 & 3.03 & $4.95 \times 10^{-4}$ \\
\hline & F1NG87 & TPR_REGION domain-containing protein & TTC28 & 8.01 & 3.00 & $2.24 \times 10^{-5}$ \\
\hline & A0A1L1RQF9 & DNA helicase & WRN & 6.67 & 2.74 & $3.19 \times 10^{-2}$ \\
\hline & A0A1L1RIR0 & FHA domain-containing protein & MCRS1 & 5.72 & 2.52 & $4.38 \times 10^{-2}$ \\
\hline & A0A1D5PHD3 & $\mathrm{C} 2 \mathrm{H} 2$-type domain-containing protein & ZNF318 & 5.30 & 2.41 & $2.86 \times 10^{-5}$ \\
\hline & Q2PC93 & SCO-spondin & SSPO & 4.26 & 2.09 & $4.20 \times 10^{-5}$ \\
\hline & A0A3Q3A731 & Uncharacterized protein & - & 3.86 & 1.95 & $3.86 \times 10^{-5}$ \\
\hline & E1C1W0 & Uncharacterized protein & TRERF1 & 3.42 & 1.77 & $4.11 \times 10^{-5}$ \\
\hline & A0A3Q2UAW2 & Rho-GAP domain-containing protein & SYDE1 & 3.16 & 1.66 & $2.17 \times 10^{-2}$ \\
\hline & $\mathrm{O} 42252$ & LIM domain-binding protein 1 & LDB1 & 2.71 & 1.44 & $7.69 \times 10^{-4}$ \\
\hline & E1BQX8 & GRIP domain-containing protein & GOLGA1 & 2.71 & 1.44 & $2.59 \times 10^{-2}$ \\
\hline & A0A3Q2U7G6 & AF-4_C domain-containing protein & AFF1 & 2.61 & 1.38 & $4.13 \times 10^{-3}$ \\
\hline & R4GGB8 & Uncharacterized protein & GAS2L3 & 2.57 & 1.36 & $1.22 \times 10^{-2}$ \\
\hline & A0A1D5PIM5 & CARMIL_C domain-containing protein & CARMIL3 & 2.42 & 1.28 & $1.66 \times 10^{-2}$ \\
\hline
\end{tabular}


Table 2. Cont.

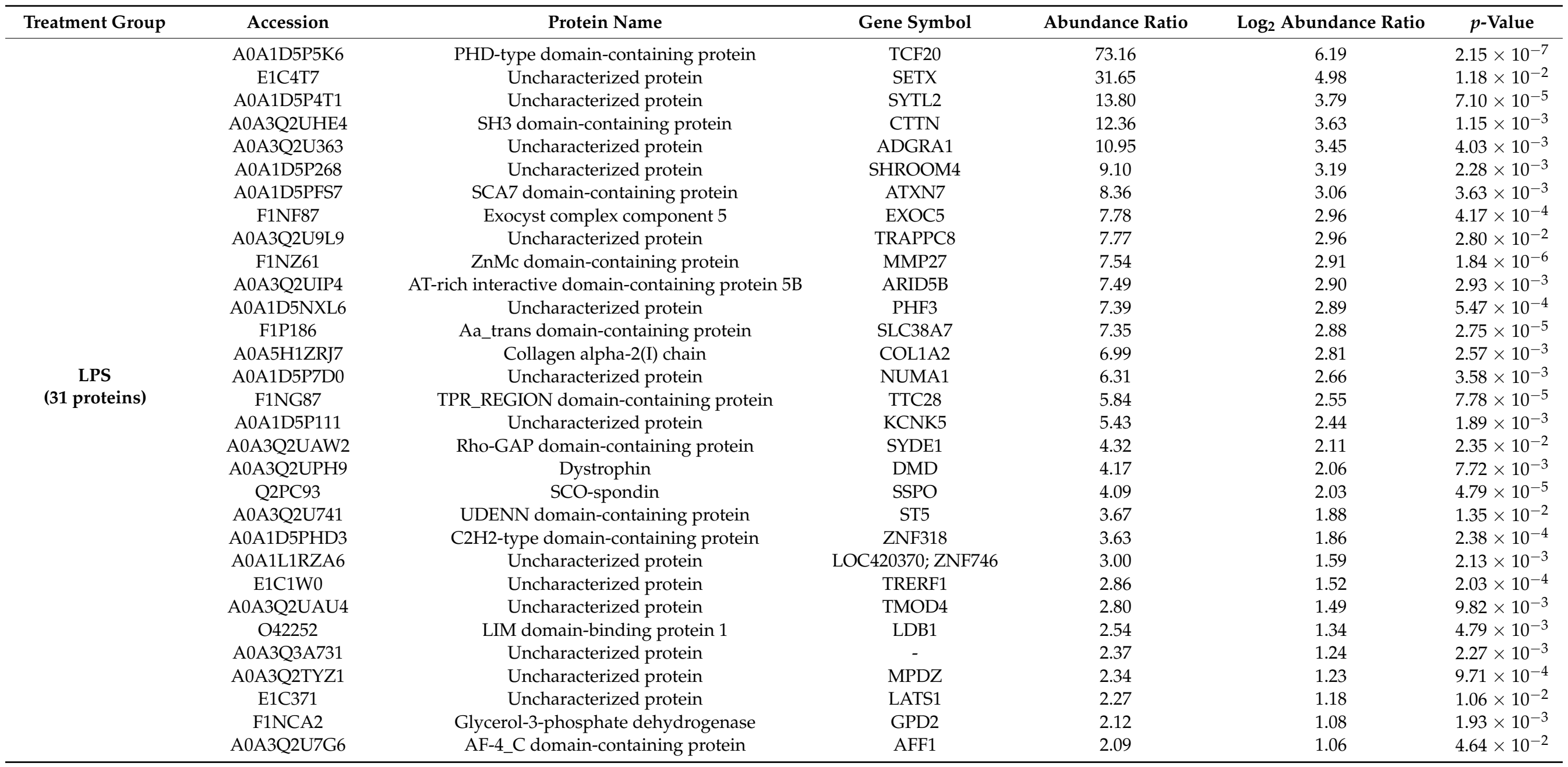


Table 2. Cont.

\begin{tabular}{|c|c|c|c|c|c|c|}
\hline Treatment Group & Accession & Protein Name & Gene Symbol & Abundance Ratio & $\log _{2}$ Abundance Ratio & $p$-Value \\
\hline \multirow{22}{*}{$\begin{array}{c}\text { PolyI:C } \\
\text { (24 proteins) }\end{array}$} & A0A3Q2U363 & Uncharacterized protein & ADGRA1 & 42.37 & 5.40 & $8.29 \times 10^{-4}$ \\
\hline & R4GGB8 & Uncharacterized protein & GAS2L3 & 39.94 & 5.32 & $8.45 \times 10^{-5}$ \\
\hline & A0A1D5PJC0 & Uncharacterized protein & - & 37.61 & 5.23 & $2.98 \times 10^{-2}$ \\
\hline & E1BYS6 & Protein kinase $\mathrm{C}$ & PKN2 & 20.82 & 4.38 & $5.94 \times 10^{-5}$ \\
\hline & A0A1D5P5K6 & PHD-type domain-containing protein & TCF20 & 17.10 & 4.10 & $1.49 \times 10^{-6}$ \\
\hline & E1BU50 & Uncharacterized protein & LOC419409 & 17.00 & 4.09 & $3.21 \times 10^{-2}$ \\
\hline & A0A1D5PJI9 & Uncharacterized protein & VPS13A & 16.70 & 4.06 & $7.82 \times 10^{-3}$ \\
\hline & F1NZ61 & ZnMc domain-containing protein & MMP27 & 15.32 & 3.94 & $7.70 \times 10^{-8}$ \\
\hline & F1P186 & Aa_trans domain-containing protein & SLC38A7 & 14.81 & 3.89 & $1.24 \times 10^{-6}$ \\
\hline & E1C1H9 & PLD phosphodiesterase domain-containing protein & PLD5 & 14.58 & 3.87 & $9.52 \times 10^{-3}$ \\
\hline & E1BQX8 & GRIP domain-containing protein & GOLGA1 & 11.87 & 3.57 & $9.02 \times 10^{-5}$ \\
\hline & E1BSS2 & Ubiquitin specific peptidase 53 & USP53 & 7.44 & 2.90 & $3.05 \times 10^{-2}$ \\
\hline & A0A1L1RVC2 & hSH3 domain-containing protein & C8H1orf168 & 6.94 & 2.80 & $2.96 \times 10^{-2}$ \\
\hline & A0A1L1RJ96 & FSA_C domain-containing protein & KIAA1109 & 6.72 & 2.75 & $3.96 \times 10^{-2}$ \\
\hline & A0A1D5P4T1 & Uncharacterized protein & SYTL2 & 6.60 & 2.72 & $3.09 \times 10^{-4}$ \\
\hline & A0A3Q2UBZ4 & Uncharacterized protein & MSLNL & 5.35 & 2.42 & $1.61 \times 10^{-3}$ \\
\hline & E1C1W0 & Uncharacterized protein & TRERF1 & 5.23 & 2.39 & $2.09 \times 10^{-6}$ \\
\hline & A0A1D5P3H2 & Guanylate cyclase & LOC107055115 & 3.20 & 1.68 & $4.59 \times 10^{-3}$ \\
\hline & A0A1D5PHD3 & $\mathrm{C} 2 \mathrm{H} 2$-type domain-containing protein & ZNF318 & 3.09 & 1.63 & $8.23 \times 10^{-4}$ \\
\hline & O42252 & LIM domain-binding protein 1 & LDB1 & 2.63 & 1.39 & $1.18 \times 10^{-3}$ \\
\hline & Q2PC93 & SCO-spondin & SSPO & 2.01 & 1.00 & $1.81 \times 10^{-2}$ \\
\hline & A0A3Q2U7G6 & AF-4_C domain-containing protein & AFF1 & 2.00 & 1.00 & $3.24 \times 10^{-2}$ \\
\hline
\end{tabular}


Table 3. Down-regulated proteins of EVs from TOCs treated with AIV, LPS, and polyI:C. Following differential expression filtering (abundance ratio $\geq 2$-fold change and $p$-value $<0.05), 36,54$, and 52 proteins were found to be down-regulated in the AIV, LPS, and polyI:C treatment groups, respectively.

\begin{tabular}{|c|c|c|c|c|c|c|}
\hline Treatment Group & Accession & Protein Name & Gene Symbol & Abundance Ratio & $\log _{2}$ Abundance Ratio & $p$-Value \\
\hline \multirow{33}{*}{$\begin{array}{c}\text { AIV } \\
\text { (36 proteins) }\end{array}$} & R4GH67 & T-box assoc domain-containing protein & EOMES & 0.01 & -6.64 & $3.38 \times 10^{-10} \times 10$ \\
\hline & A0A1D5PVY2 & Uncharacterized protein & EHMT1 & 0.01 & -6.64 & $1.35 \times 10^{-6}$ \\
\hline & E1C1D1 & Annexin & ANXA7 & 0.02 & -6.03 & $2.43 \times 10^{-5}$ \\
\hline & E1C5B4 & Enhancer of polycomb homolog & EPC1 & 0.05 & -4.36 & $9.67 \times 10^{-5}$ \\
\hline & A0A3Q2ТTI8 & Zinc finger protein 644 & ZNF644 & 0.06 & -4.05 & $3.77 \times 10^{-2}$ \\
\hline & A0A1D5PPP1 & Uncharacterized protein & RGS14 & 0.06 & -3.98 & $3.40 \times 10^{-5}$ \\
\hline & A0A1D5PQ57 & Phosphoinositide phospholipase $C$ & PLCE1 & 0.07 & -3.84 & $7.81 \times 10^{-3}$ \\
\hline & E1BU62 & DOP1 leucine zipper like protein B & & 0.07 & -3.78 & $1.33 \times 10^{-4}$ \\
\hline & E1C8W5 & Uncharacterized protein & CHST15 & 0.1 & -3.27 & $1.75 \times 10^{-4}$ \\
\hline & F1NPH9 & OMPdecase & UMPS & 0.11 & -3.21 & $7.57 \times 10^{-3}$ \\
\hline & E1C8S3 & $\mathrm{S} 1$ motif domain-containing protein & SRBD1 & 0.11 & -3.13 & $1.27 \times 10^{-7}$ \\
\hline & A0A1D5PJ72 & Capping protein inhibiting regulator of actin dynamics & & 0.12 & -3.08 & $1.46 \times 10^{-5}$ \\
\hline & A0A1D5P7I8 & Zinc finger protein 516 & ZNF516 & 0.12 & -3.03 & $1.01 \times 10^{-3}$ \\
\hline & A0A3Q2U3A1 & Uncharacterized protein & & 0.13 & -2.92 & $1.53 \times 10^{-2}$ \\
\hline & A0A3O3ANH5 & Uncharacterized protein & & 0.16 & -2.69 & $5.39 \times 10^{-4}$ \\
\hline & E1BQG1 & Uncharacterized protein & TNRC6B & 0.16 & -2.66 & $2.82 \times 10^{-4}$ \\
\hline & A0A1D5P251 & Uncharacterized protein & MAP1S & 0.16 & -2.66 & $4.85 \times 10^{-2}$ \\
\hline & F1NF87 & Exocyst complex component 5 & EXOC5 & 0.16 & -2.62 & $6.70 \times 10^{-4}$ \\
\hline & A0A3Q2UHA1 & Uncharacterized protein & FAAP100 & 0.17 & -2.59 & $2.83 \times 10^{-2}$ \\
\hline & R4GGE1 & Uncharacterized protein & SATB1 & 0.19 & -2.41 & $5.86 \times 10^{-4}$ \\
\hline & А0А3О3А6T8 & Uncharacterized protein & ALMS1 & 0.21 & -2.24 & $2.06 \times 10^{-2}$ \\
\hline & A0A1D5PPH7 & UnbV_ASPIC domain-containing protein & CRTAC1 & 0.22 & -2.2 & $1.03 \times 10^{-3}$ \\
\hline & A0A1D5NU15 & Uncharacterized protein & MAGI1 & 0.24 & -2.04 & $1.43 \times 10^{-3}$ \\
\hline & F1NEI8 & Poly(A)-specific ribonuclease PARN & PARN & 0.29 & -1.8 & $2.59 \times 10^{-4}$ \\
\hline & E1BYA8 & Uncharacterized protein & ERCC6 & 0.29 & -1.78 & $3.96 \times 10^{-6}$ \\
\hline & A0A1D5P3H2 & Guanylate cyclase & LOC107055115 & 0.31 & -1.67 & $2.09 \times 10^{-2}$ \\
\hline & A0A3Q2TSU2 & HECT-type E3 ubiquitin transferase & NEDD4L & 0.35 & -1.53 & $6.02 \times 10^{-3}$ \\
\hline & A0A1D5P0N4 & Transcriptional activator Myb & MYB & 0.39 & -1.38 & $7.61 \times 10^{-3}$ \\
\hline & A0A3O2U624 & Uncharacterized protein & WDR62 & 0.39 & -1.38 & $3.58 \times 10^{-2}$ \\
\hline & A0A1D5P124 & Uncharacterized protein & ANK2 & 0.39 & -1.34 & $4.80 \times 10^{-2}$ \\
\hline & A0A1D5PCT6 & Kinesin-like protein & KIF23 & 0.47 & -1.08 & $1.56 \times 10^{-2}$ \\
\hline & H9KYN7 & Peptidase S1 domain-containing protein & $\begin{array}{c}\text { LOC431235; CTRB2; } \\
\text { LOC100859877; } \\
\text { CTRB1 }\end{array}$ & 0.47 & -1.08 & $4.57 \times 10^{-2}$ \\
\hline & F1NWT3 & F-box domain-containing protein & FBXO5 & 0.48 & -1.06 & $1.20 \times 10^{-2}$ \\
\hline
\end{tabular}


Table 3. Cont.

\begin{tabular}{|c|c|c|c|c|c|c|}
\hline Treatment Group & Accession & Protein Name & Gene Symbol & Abundance Ratio & $\log _{2}$ Abundance Ratio & $p$-Value \\
\hline \multirow{38}{*}{$\begin{array}{c}\text { LPS } \\
\text { (54 proteins) }\end{array}$} & A0A1D5NUX8 & Uncharacterized protein & SLC25A10 & 0.01 & -6.64 & $5.15 \times 10^{-13}$ \\
\hline & A0A1D5P8P3 & Collagen IV NC1 domain-containing protein & COL4A1 & 0.01 & -6.64 & $2.19 \times 10^{-10}$ \\
\hline & R4GH67 & T-box_assoc domain-containing protein & EOMES & 0.01 & -6.64 & $4.54 \times 10^{-9}$ \\
\hline & A0A1D5PCP1 & Uncharacterized protein & ERICH3 & 0.01 & -6.64 & $3.02 \times 10^{-5}$ \\
\hline & F1NN69 & Beta-1,4-N-acetylgalactosaminyltransferase & B4GALNT3 & 0.01 & -6.26 & $2.38 \times 10^{-7}$ \\
\hline & A0A3Q2TZW2 & Transcription initiation factor TFIID subunit & RHOGL & 0.02 & -6.06 & $8.70 \times 10^{-4}$ \\
\hline & A0A1D5NZF5 & BHLH domain-containing protein & USF3 & 0.02 & -5.62 & $1.45 \times 10^{-5}$ \\
\hline & E1C7T1 & SERPIN domain-containing protein & SERPINA1; SPIA1 & 0.02 & -5.39 & $5.88 \times 10^{-8}$ \\
\hline & A0A3Q2UIH4 & Zyxin & ZYX & 0.03 & -5.25 & $6.78 \times 10^{-4}$ \\
\hline & F1NT94 & Histone acetyltransferase & KAT6A & 0.03 & -5.12 & $4.61 \times 10^{-4}$ \\
\hline & F1NLF0 & Uncharacterized protein & EPS15 & 0.03 & -4.88 & $1.16 \times 10^{-4}$ \\
\hline & E1BU88 & Treslin N domain-containing protein & C10H15orf42; TICRR & 0.04 & -4.73 & $2.73 \times 10^{-2}$ \\
\hline & R4GLP0 & Cytochrome c oxidase polypeptide VIIc & COX7C & 0.04 & -4.67 & $3.42 \times 10^{-3}$ \\
\hline & E1BU62 & DOP1 leucine zipper like protein B & & 0.05 & -4.24 & $5.30 \times 10^{-4}$ \\
\hline & E1BTE7 & AAA domain-containing protein & TOR3A & 0.06 & -3.96 & $1.21 \times 10^{-3}$ \\
\hline & F1NV58 & Uncharacterized protein & SPTBN5 & 0.07 & -3.83 & $7.92 \times 10^{-3}$ \\
\hline & A0A3Q2U9U5 & Ig-like domain-containing protein & ILDR2 & 0.07 & $\begin{array}{l}-3.03 \\
-3.81\end{array}$ & $1.92 \times 100$ \\
\hline & A0A1D5NW78 & Uncharacterized protein & SPAG17 & 0.07 & -3.76 & $1.30 \times 10^{-4}$ \\
\hline & A0A3Q3A6T8 & Uncharacterized protein & ALMS1 & 0.08 & -3.73 & $4.11 \times 10^{-4}$ \\
\hline & A0A1D5P0N4 & Transcriptional activator Myb & MYB & 0.08 & -3.69 & $8.29 \times 10^{-6}$ \\
\hline & E1C309 & Uncharacterized protein & SLC25A19 & 0.08 & -3.66 & $1.76 \times 10^{-3}$ \\
\hline & E1C1D1 & Annexin & ANXA7 & 0.08 & -3.64 & $4.26 \times 10^{-4}$ \\
\hline & A0A1D5PVP9 & Protogenin & PRTG & 0.09 & -3.53 & $2.84 \times 10^{-2}$ \\
\hline & E1C8S3 & S1 motif domain-containing protein & SRBD1 & 0.09 & -3.45 & $5.11 \times 10^{-8}$ \\
\hline & F1NDM4 & Origin recognition complex subunit 2 & ORC2 & 0.09 & -3.43 & $3.49 \times 10^{-3}$ \\
\hline & F1NJM6 & Uncharacterized protein & $\begin{array}{l}\text { LOC100857368; } \\
\text { ZCCHC6 }\end{array}$ & 0.1 & -3.4 & $1.16 \times 10^{-6}$ \\
\hline & F1NHH4 & Fibrillar collagen NC1 domain-containing protein & COL27A1 & 0.11 & -3.17 & $1.39 \times 10^{-4}$ \\
\hline & E1BQP5 & Uncharacterized protein & WDR72 & 0.12 & -3.11 & $1.17 \times 10^{-2}$ \\
\hline & A0A3Q2TSU2 & HECT-type E3 ubiquitin transferase & NEDD4L & 0.12 & -3.03 & $2.64 \times 10^{-5}$ \\
\hline & R4GGE1 & Uncharacterized protein & SATB1 & 0.15 & -2.71 & $1.19 \times 10^{-3}$ \\
\hline & A0A1D5PVY2 & Uncharacterized protein & EHMT1 & 0.16 & -2.65 & $8.64 \times 10^{-3}$ \\
\hline & E1C8W5 & Uncharacterized protein & CHST15 & 0.17 & -2.6 & $6.38 \times 10^{-4}$ \\
\hline & R4GFN5 & Uncharacterized protein & GRIN2C; LOC431090 & 0.17 & -2.55 & $3.10 \times 10^{-3}$ \\
\hline & F1NWT3 & F-box domain-containing protein & FBXO5 & 0.19 & -2.41 & $6.47 \times 10^{-4}$ \\
\hline & A0A1D5P124 & Uncharacterized protein & ANK2 & 0.19 & -2.4 & $1.12 \times 10^{-2}$ \\
\hline & E1C5B4 & Enhancer of polycomb homolog & EPC1 & 0.2 & -2.33 & $1.26 \times 10^{-2}$ \\
\hline & A0A3Q2U888 & Rhomboid domain-containing protein & RHBDF2 & 0.2 & -2.31 & $\begin{array}{l}1.20 \times 10 \\
1.61 \times 10^{-2}\end{array}$ \\
\hline & P08287 & Histone H1.11L & $\begin{array}{l}\text { HIST1H111L; } \\
\text { HIST1H1C }\end{array}$ & 0.21 & -2.26 & $1.73 \times 10^{-3}$ \\
\hline
\end{tabular}


Table 3. Cont.

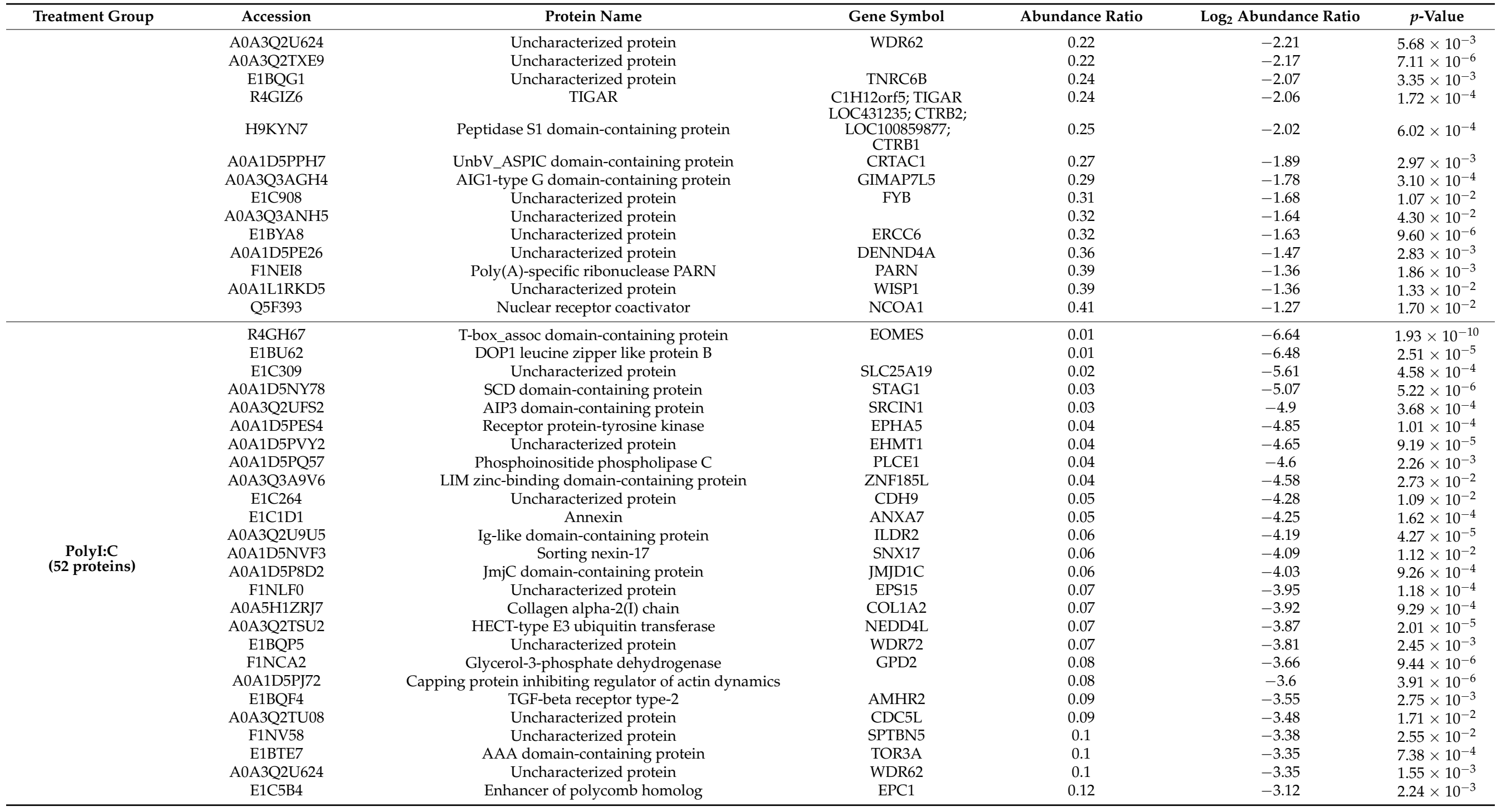


Table 3. Cont.

\begin{tabular}{|c|c|c|c|c|c|c|}
\hline Treatment Group & Accession & Protein Name & Gene Symbol & Abundance Ratio & $\log _{2}$ Abundance Ratio & $p$-Value \\
\hline & A0A1D5P1A1 & Uncharacterized protein & C5H11ORF9 & 0.12 & -3.08 & $2.26 \times 10^{-2}$ \\
\hline & A0A3Q2UHA1 & Uncharacterized protein & FAAP100 & 0.12 & -3.03 & $4.32 \times 10^{-2}$ \\
\hline & R4GGE1 & Uncharacterized protein & SATB1 & 0.13 & -2.91 & $1.04 \times 10^{-4}$ \\
\hline & P08287 & Histone H1.11L & $\begin{array}{l}\text { HIST1H111L; } \\
\text { HIST1H1C }\end{array}$ & 0.14 & -2.86 & $2.58 \times 10^{-4}$ \\
\hline & A0A3Q2UG75 & Ras-responsive element-binding protein 1 & RREB1 & 0.14 & -2.82 & $3.39 \times 10^{-2}$ \\
\hline & E1C8S3 & S1 motif domain-containing protein & SRBD1 & 0.16 & -2.69 & $7.57 \times 10^{-7}$ \\
\hline & A0A3Q3ANH5 & Uncharacterized protein & & 0.17 & -2.53 & $3.83 \times 10^{-4}$ \\
\hline & F1NWT3 & F-box domain-containing protein & FBXO5 & 0.18 & -2.5 & $1.02 \times 10^{-4}$ \\
\hline & A0A3Q2U0V9 & Uncharacterized protein & SLC11A2 & 0.18 & -2.47 & $1.82 \times 10^{-2}$ \\
\hline & A0A1D5P0N4 & Transcriptional activator $\mathrm{Myb}$ & MYB & 0.22 & -2.22 & $1.91 \times 10^{-3}$ \\
\hline & A0A3Q3A6T8 & Uncharacterized protein & ALMS1 & 0.22 & -2.22 & $2.09 \times 10^{-2}$ \\
\hline & A0A1D5PD16 & Uncharacterized protein & DNAH10 & 0.23 & -2.14 & $2.01 \times 10^{-3}$ \\
\hline & A0A1L1RX59 & Diadenosine tetraphosphate synthetase & GARS & 0.24 & -2.09 & $2.08 \times 10^{-2}$ \\
\hline & A0A1D5PBZ9 & Protein-tyrosine-phosphatase & PTPRB & 0.24 & -2.05 & $1.48 \times 10^{-3}$ \\
\hline & F1P5A5 & $28 \mathrm{~S}$ ribosomal protein S31, mitochondrial & MRPS31 & 0.26 & -1.97 & $6.18 \times 10^{-3}$ \\
\hline & E1BQG1 & Uncharacterized protein & TNRC6B & 0.26 & -1.92 & $4.09 \times 10^{-3}$ \\
\hline & A0A3Q2U888 & Rhomboid domain-containing protein & RHBDF2 & 0.27 & -1.9 & $4.90 \times 10^{-2}$ \\
\hline & A0A1D5P7I8 & Zinc finger protein 516 & ZNF516 & 0.3 & -1.74 & $1.50 \times 10^{-2}$ \\
\hline & H9KYN7 & Peptidase S1 domain-containing protein & $\begin{array}{c}\text { LOC431235; CTRB2; } \\
\text { LOC100859877; } \\
\text { CTRB1 }\end{array}$ & 0.31 & -1.67 & $3.00 \times 10^{-3}$ \\
\hline & A0A1D5PGG8 & Nucleolar complex protein 3 homolog & NOC3L & 0.36 & -1.48 & $6.74 \times 10^{-3}$ \\
\hline & A0A3Q2U9J3 & Ubiquitinyl hydrolase 1 & OTUD7A & 0.38 & -1.38 & $9.29 \times 10^{-3}$ \\
\hline & F1NQ24 & Uncharacterized protein & DENND4C & 0.39 & -1.37 & $5.08 \times 10^{-3}$ \\
\hline & F1NEI8 & Poly(A)-specific ribonuclease PARN & PARN & 0.42 & -1.25 & $4.00 \times 10^{-3}$ \\
\hline & A0A3Q2TXE9 & Uncharacterized protein & & 0.47 & -1.09 & $5.90 \times 10^{-3}$ \\
\hline
\end{tabular}


AIV vs. CTRL

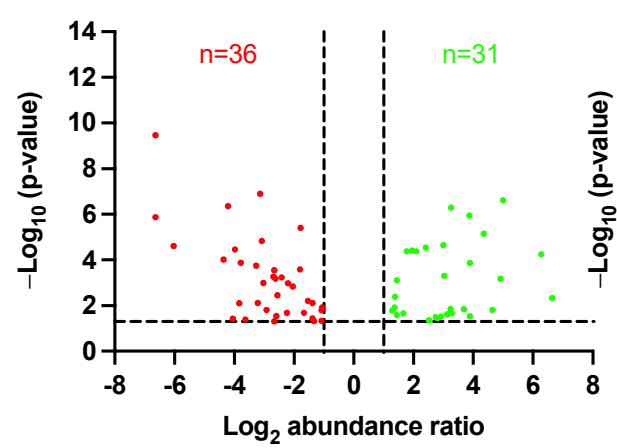

(a)
LPS vs. CTRL

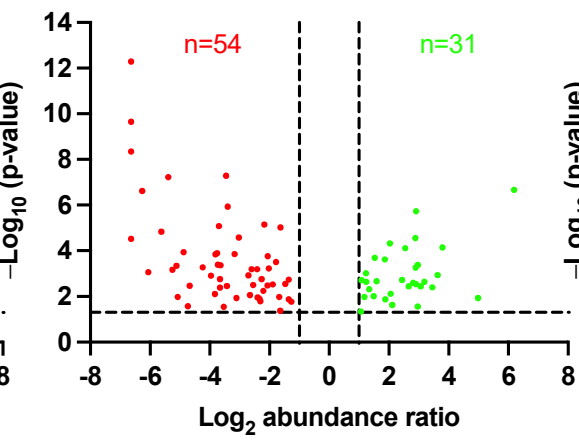

(b)
Polyl:C vs. CTRL

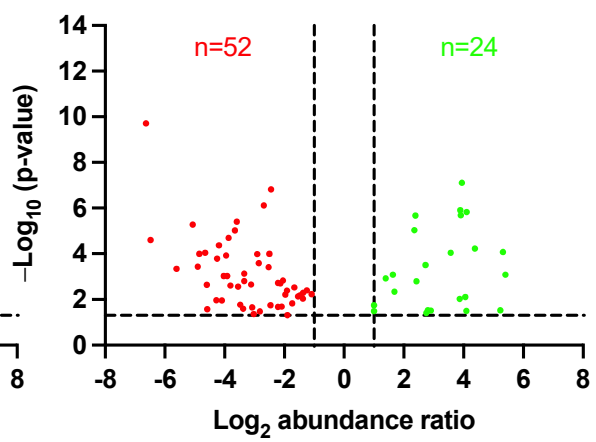

(c)

Figure 1. Volcano plots showing DE proteins of EVs from TOCs treated with (a) AIV, (b) LPS, and (c) polyI:C. The horizontal dotted line represents the $p$-value $<0.05$ threshold. Up-regulated proteins are represented by green data points and down-regulated proteins are represented by red data points. The vertical dotted lines represent the abundance ratio $\geq 2$-fold change threshold. Lists of the upand down-regulated proteins for AIV, LPS, and polyI:C treatment groups are shown in Tables 2 and 3, respectively.

Differentially expressed proteins

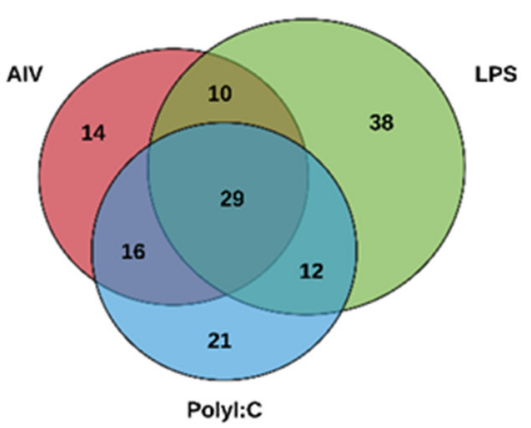

Up-regulated proteins

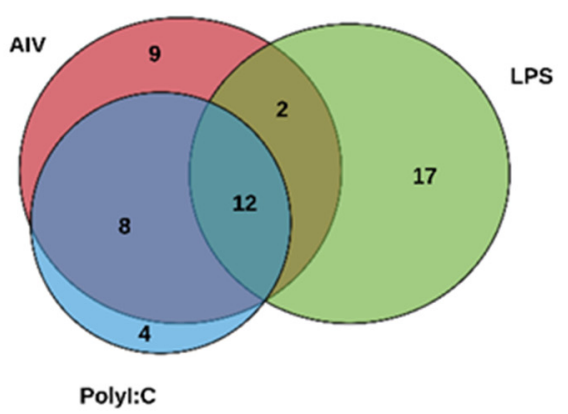

Down-regulated proteins

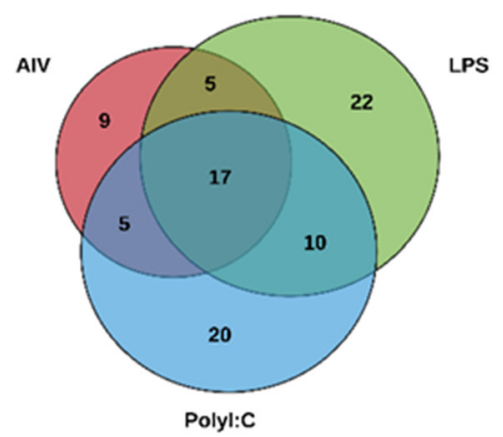

Figure 2. Venn diagram showing DE proteins of EVs from TOCs treated with (a) AIV, (b) LPS, and (c) polyI:C. Lists of the up- and down-regulated proteins for AIV, LPS, and polyI:C treatment groups and intersections of groups are shown in Table S2.

\subsection{Proteins Found in EVs Released from TOCs Have Functions in Cell Signaling and Immune System Processes}

Following differential expression filtering of the proteins, GO analysis was performed to identify the proteome component characteristics. The associated terms for biological process, molecular function, cellular component, protein class, and pathways were determined using the PANTHER database [42]. Overall, the GO analysis characterized common and differing characteristics among the different EV treatment groups (Figure 3 and Table S3). Concerning molecular function terms, all groups had a high proportion of up- and down-regulated proteins associated with the general terms "catalytic activity" and "binding" (Figure 3a,b). For analysis of biological process terms, up-regulated proteins were associated with categories such as "signaling" and "response to stimulus" terms (Figure 3c). More specifically, the proteins in associated to "signaling" were ADGRA1/GPR123 (A0A3Q2U363) (common to all three treatment groups), IGF1R (A0A1D5PVH7) (AIV group), LATS1 (E1C371) (LPS group), and PKN2 (E1BYS6) (polyI:C group). The proteins associated with "response to stimulus" were ADGRA1/GPR123 (A0A3Q2U363) (common to all three treatment groups), USP53 (E1BSS2) (common to AIV and polyI:C groups), LATS1 (E1C371) (LPS group), and PKN2 (E1BYS6) (polyI:C group). In contrast, down-regulated proteins were associated with "signaling" and "response to stimulus" as well, but also with the term "immune system process" (Figure 3d). The proteins associated with "signaling" were PLCE1 (A0A1D5PQ57) 
(common to AIV and polyI:C groups), RHBDF2 (A0A3Q2U888) (common to LPS and polyI:C groups), MAGI1 (A0A1D5NU15) (AIV group), WISP1 (A0A1L1RKD5), COL27A1 (F1NHH4), DENND4A (A0A1D5PE26), FYB (E1C908), GRIN2C (R4GFN5), and ZYX (A0A3Q2UIH4) (LPS group), and DENND4C (F1NQ24), STAG1 (A0A1D5NY78), EPHA5 (A0A1D5PES4), and AMHR2/Gga.10225 (E1BQF4) (polyI:C group). The proteins associated to "response to stimulus" were EOMES (R4GH67) (common to all three treatment groups), PLCE1 (A0A1D5PQ57) (common to AIV and polyI:C groups), NCOA1 (Q5F393) and RHBDF2 (A0A3Q2U888) (common to LPS and polyI:C groups), MAGI1 (A0A1D5NU15) (AIV group), TICRR (E1BU88), WISP1 (A0A1L1RKD5), COL27A1 (F1NHH4), DENND4A (A0A1D5PE26), FYB (E1C908), GRIN2C (R4GFN5), TIGAR (R4GIZ6), and ZYX (A0A3Q2UIH4) (LPS group), and DENND4C (F1NQ24), STAG1 (A0A1D5NY78), EPHA5 (A0A1D5PES4), and AMHR2/Gga.10225 (E1BQF4) (polyI:C group).The proteins associated to "immune system process" were EOMES (R4GH67) (common to all three treatment groups) and FYB (E1C908) (LPS group). Furthermore, the proportions for cellular component categories for both and up- and down-regulated proteins of all groups were similar, with the highest proportion of percent gene hits being for "cellular anatomical complex", followed by "intracellular" and, finally, "protein-containing complex" (Figure 3e,f). Finally, concerning protein component terms, the category with one of the highest percent of gene hits for up- and down-regulated proteins was gene-specific transcriptional regulators (Figure $3 \mathrm{~g}, \mathrm{~h}$ ).

To gain a better understanding of the role the identified DE proteins, functional annotation for pathways were obtained from the PANTHER classification system database and used to build a network (Figure 4 and Table S4). In the AIV treatment group, downregulated proteins PLCE1 (A0A1D5PQ57) and RGS14 (A0A1D5PPP1) were found to be associated with the inflammation mediated by chemokine and cytokine signaling pathways, and down-regulated protein WRN (A0A1L1RQF9) was found to be associated with the p53 pathway (Figure 4a). In the LPS treatment group, up-regulated proteins COL4A1 (A0A1D5P8P3) and COL27A1 (F1NHH4) and down-regulated protein COL1A2 (A0A5H1ZRJ7) were found to be associated with the integrin signaling pathways (Figure $4 \mathrm{~b}$ ). In the polyI:C treatment group, the inflammation mediated by chemokine and cytokine signaling pathwayassociated down-regulated protein PLCE1 (A0A1D5PQ57) was also identified. Furthermore, up-regulated protein AMHR2/Gga.10225 (E1BQF4) was found to be associated with the TGF-beta signaling pathway, and the up-regulated protein COL1A2 (A0A5H1ZRJ7) was found to be associated with the integrin signaling pathways. Finally, the up-regulated protein CDH9 (E1C264) was found to be associated with the cadherin signaling and the Wnt signaling pathways (Figure 4c). Moreover, to illustrate and increase the overall understanding of the relationships between the identified DE proteins, protein-protein interaction networks were built using the STRING database (Figure S1). The results of this analysis demonstrate a connected network of proteins within the different treatment groups. For example, in the AIV up-regulated treatment group, we found interactions between the proteins SSPO (Q2PC93), ADGRA1/GPR123 (A0A3Q2U363), PAPLN (A0A1D5P8Q3), FRAS1 (F1NX10), and ARID5B (A0A3Q2UIP4). In the LPS down-regulated group, we found interactions between KAT6A (F1NT94), RHOGL (A0A3Q2TZW2), EPC1 (E1C5B4), and EHMT1 (A0A1D5PVY2), as well as between ANK2 (A0A1D5P124) and SPTBN5 (F1NV58). 
Molecular Function - Up-Regulated

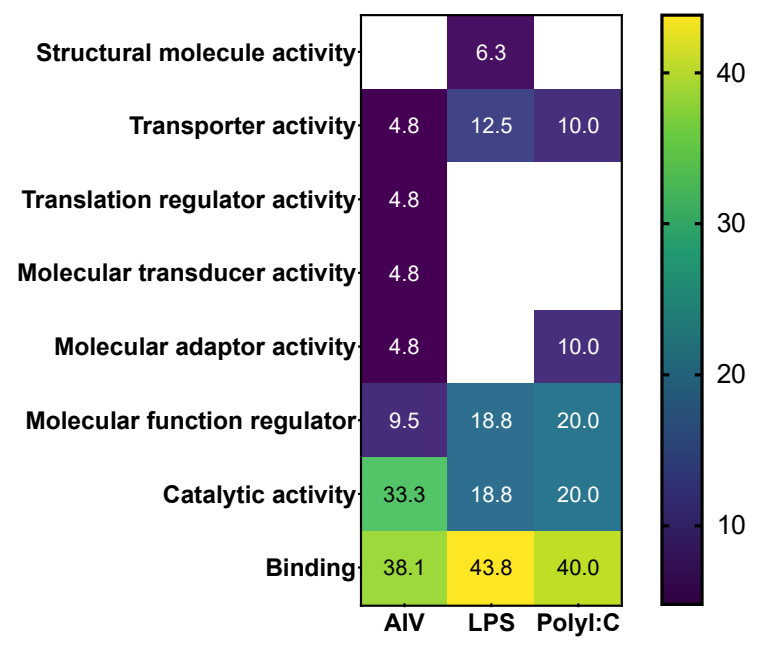

(a)

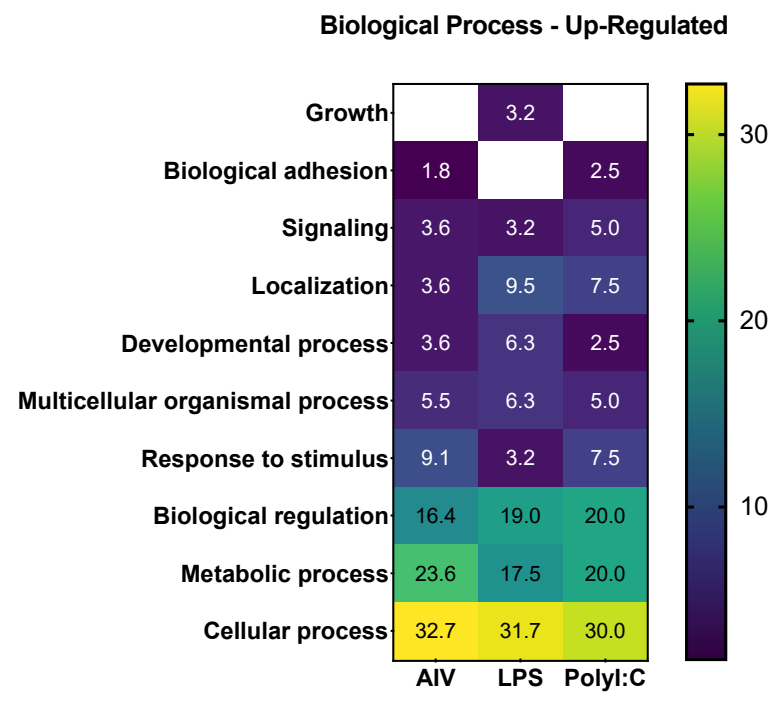

(c)

Figure 3. Cont.
Molecular Function - Down-Regulated

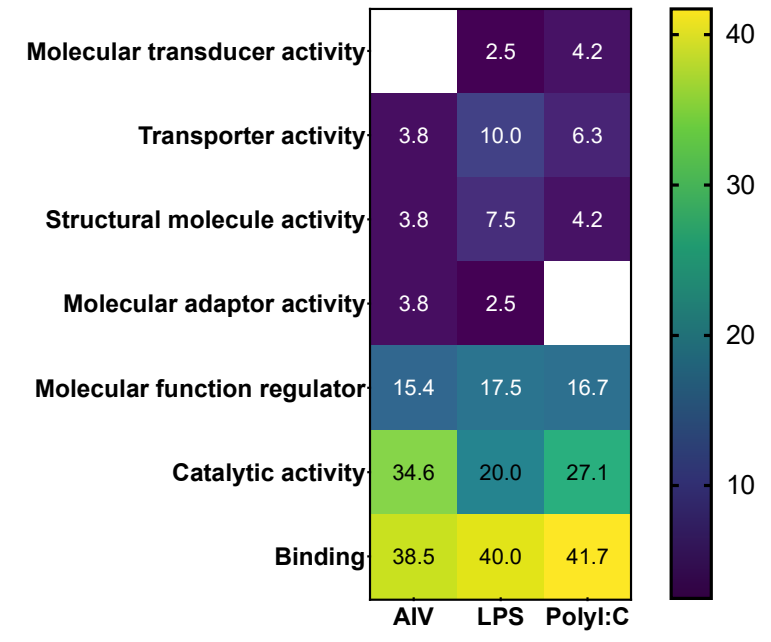

(b)

Biological Process - Down-Regulated

\begin{tabular}{|c|c|c|c|}
\hline Locomotion & & & 0.9 \\
\hline Biological adhesion & & 0.9 & 0.9 \\
\hline Reproductive process & 1.5 & 0.9 & 0.9 \\
\hline Reproduction & 1.5 & 0.9 & 0.9 \\
\hline Immune system process & 1.5 & 0.9 & 0.9 \\
\hline Signaling & 3.0 & 6.4 & 5.5 \\
\hline Response to stimulus & 4.5 & 10.0 & 7.3 \\
\hline Localization & 4.5 & 8.2 & 4.6 \\
\hline Multicellular organismal process & 6.0 & 4.5 & 5.5 \\
\hline Developmental process & 6.0 & 3.6 & 5.5 \\
\hline Biological regulation & 19.4 & 20.0 & 17.4 \\
\hline Metabolic process & 20.9 & 14.5 & 19.3 \\
\hline \multirow[t]{2}{*}{ Cellular process } & 31.3 & 28.2 & 30.3 \\
\hline & AlV & LPS & olyl: \\
\hline
\end{tabular}

(d) 


\section{Cellular Component - Up-Regulated}

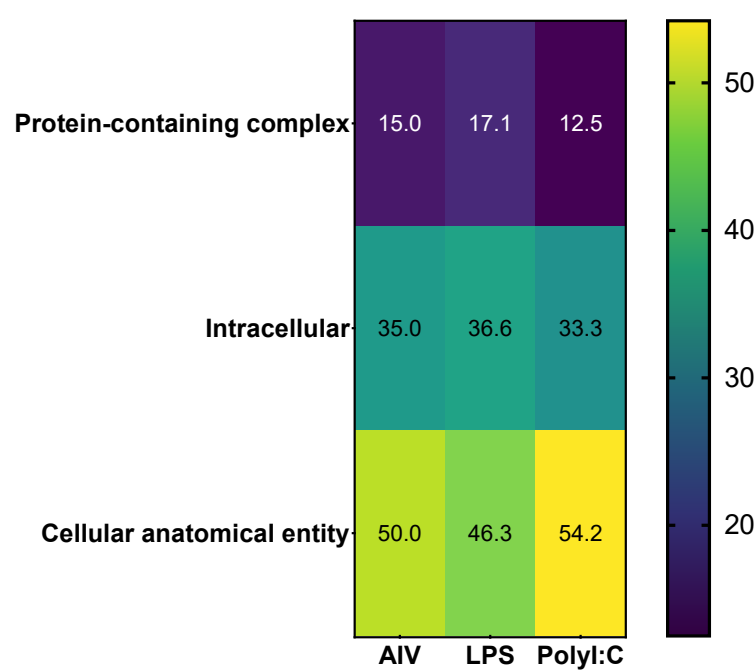

(e)

Protein Component - Up-Regulated

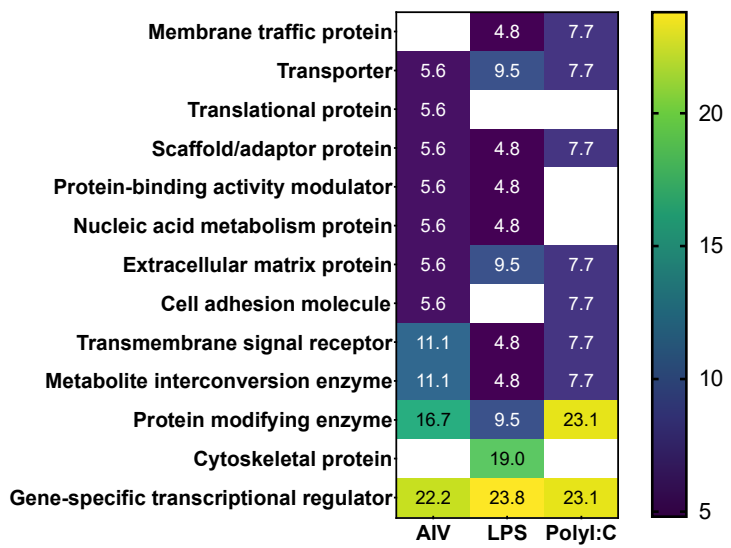

(g)

50

30
Cellular Component - Down-Regulated

Cellular anatomical entity

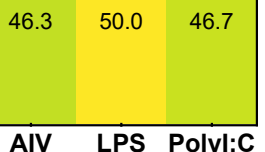

(f)

Protein Component - Down-Regulated

\begin{tabular}{|c|c|c|c|}
\hline \\
\hline Cell adhesion molecule & & & 3.2 \\
\hline Transmembrane signal receptor & & 3.3 & 9.7 \\
\hline Scaffold/adaptor protein & & 3.3 & 3.2 \\
\hline Protein-binding activity modulator & & 3.3 & \\
\hline Intercellular signal molecule & & 3.3 & \\
\hline Defense/immunity protein & & 3.3 & 3.2 \\
\hline Chaperone & & 3.3 & 3.2 \\
\hline Transporter- & & 6.7 & 6.5 \\
\hline Extracellular matrix protein & & 6.7 & 3.2 \\
\hline Membrane traffic protein & 5.6 & 3.3 & 3.2 \\
\hline Calcium-binding protein & 5.6 & 3.3 & 3.2 \\
\hline natin-binding, or -regulatory protein & 5.6 & 10.0 & 12.9 \\
\hline Translational protein & 11.1 & 3.3 & 9.7 \\
\hline Cytoskeletal protein & 11.1 & 3.3 & 3.2 \\
\hline Nucleic acid metabolism protein & 11.1 & 10.0 & 6.5 \\
\hline e-specific transcriptional regulator & 16.7 & 6.7 & 9.7 \\
\hline Protein modifying enzyme & 16.7 & 13.3 & 12.9 \\
\hline Metabolite interconversion enzyme & 16.7 & 13.3 & 6.5 \\
\hline & AIV & LPS & olyl:C \\
\hline
\end{tabular}

Figure 3. Gene set enrichment analysis of DE proteins of EVs from TOCs treated with AIV, LPS, and polyI:C. Separated by up-regulated and down-regulated proteins, the functional annotation for molecular function $(\mathbf{a}, \mathbf{b})$, biological process $(\mathbf{c}, \mathbf{d})$, cellular component $(\mathbf{e}, \mathbf{f})$, and protein class $(\mathbf{g}, \mathbf{h})$, respectively, were obtained from the PANTHER classification system database. The color intensities represent the percent gene hits against the total number of hits for each term. Detailed lists of the upand down-regulated proteins and associated gene ontology terms for AIV, LPS, and polyI:C treatment groups are found in Table S3. 

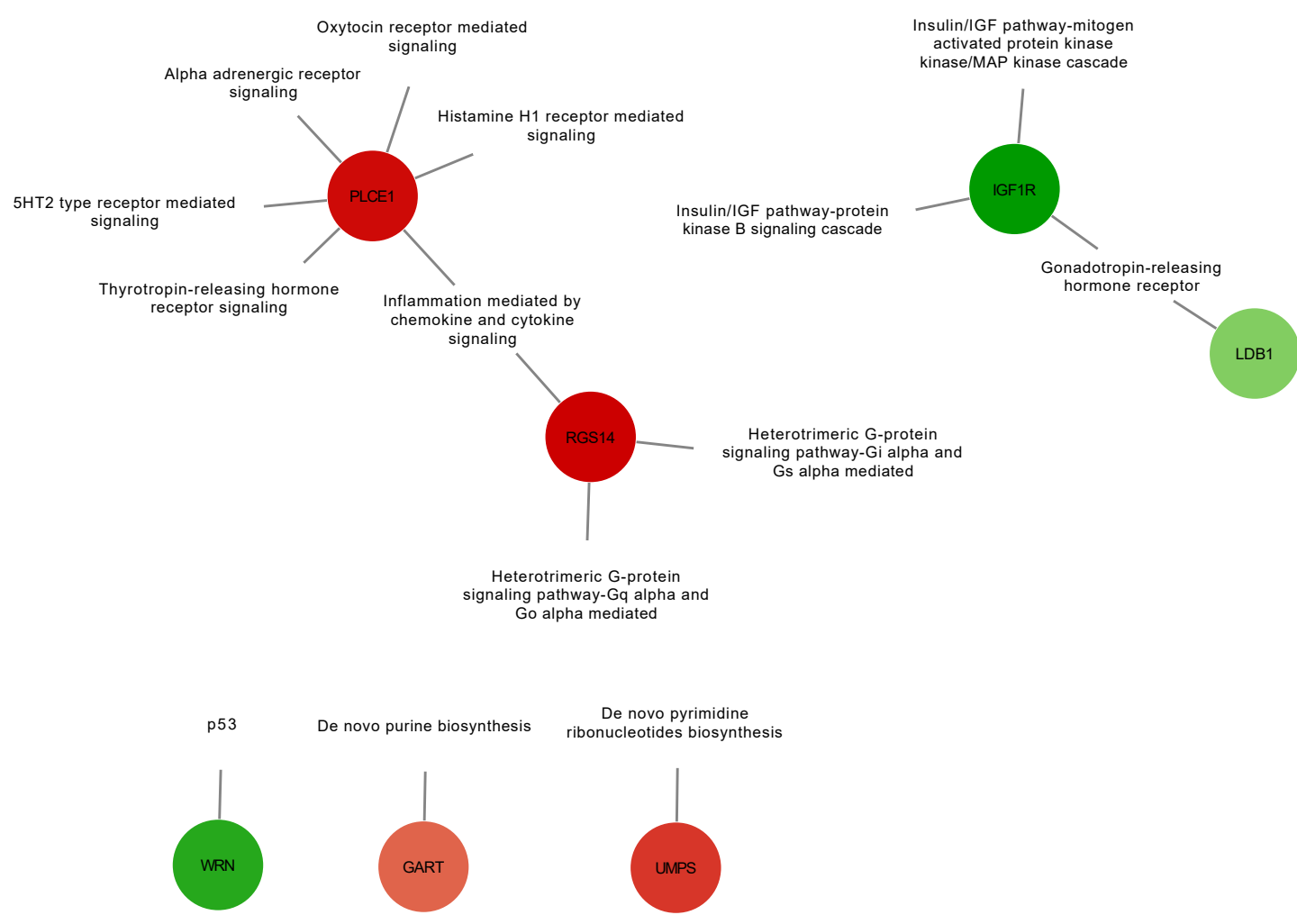

(a)
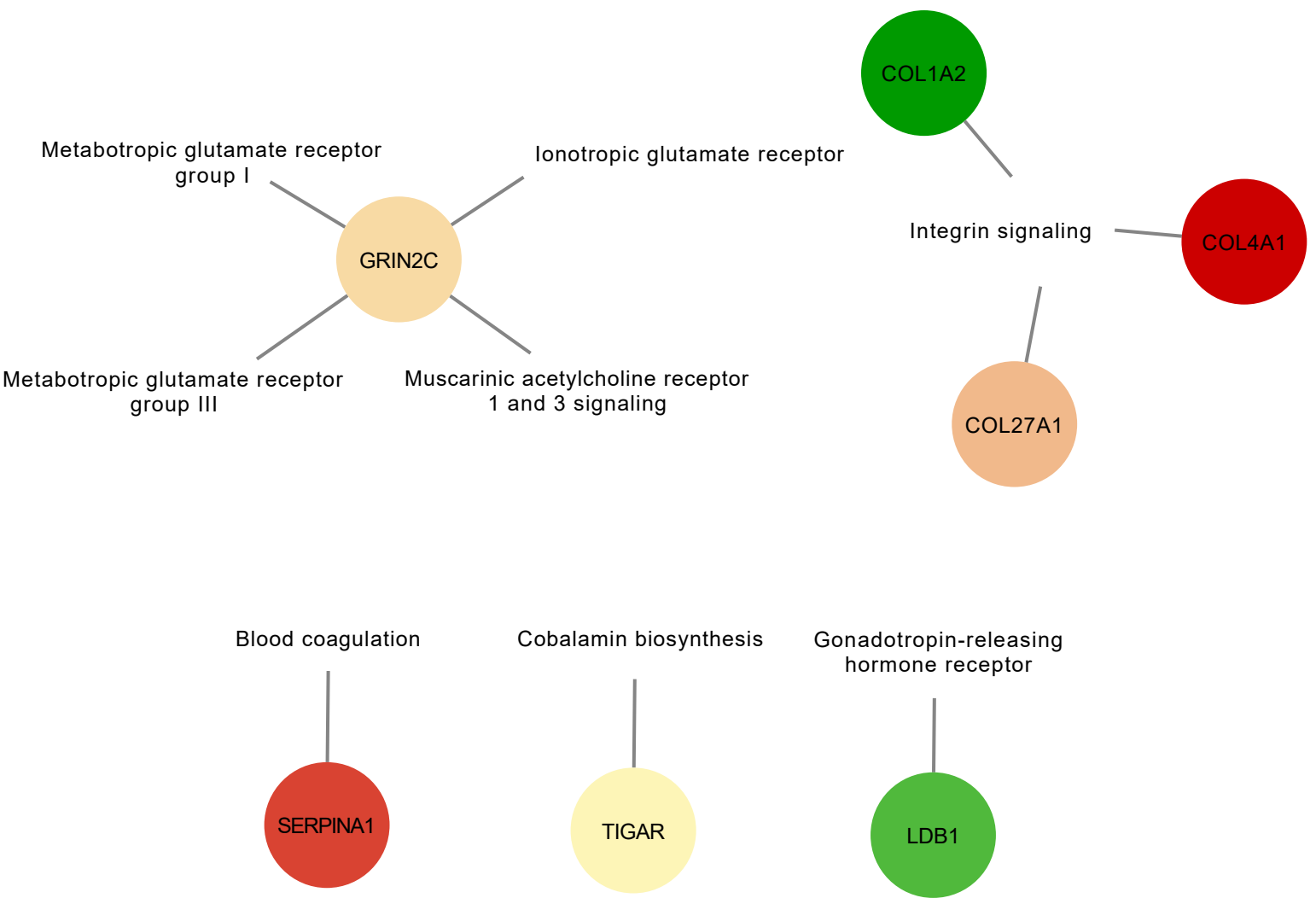

Cobalamin biosynthesis

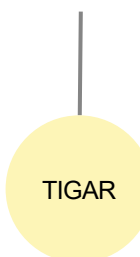

(b)

Figure 4. Cont. 


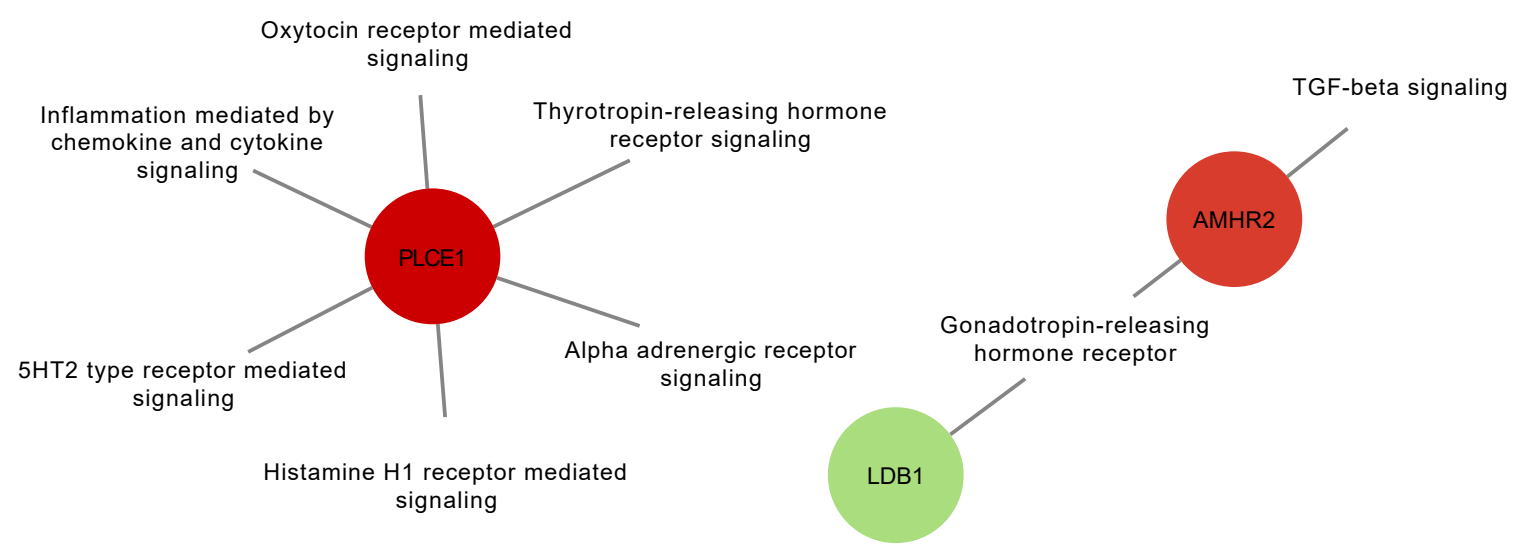

PDGF signaling

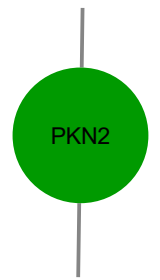

Muscarinic acetylcholine receptor 1 and 3 signaling
Cadherin signaling

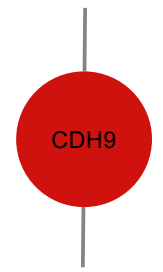

Wnt signaling

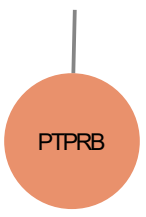

De novo purine biosynthesis

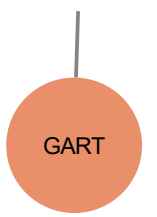

Integrin signaling

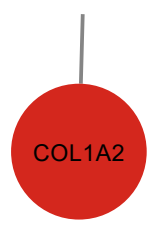

(c)

Figure 4. Gene set enrichment analysis of up-regulated and down-regulated proteins of EVs from TOCs treated with AIV (a), LPS (b), and polyI:C (c). Functional annotation for selected pathways was obtained from the PANTHER classification system database. Pathway enrichment results are shown as a network with nodes colored based on relative abundance (compared to EV control treatment group). Selected up-regulated proteins are shown in green, whereas down-regulated proteins are shown in red. The complete lists of up- and down-regulated proteins for AIV, LPS, and polyI:C treatment groups are shown in Table S4.

\subsection{EVs Released from TOCs Impact Chicken Macrophage Functions}

To determine whether chicken macrophages can uptake EVs, fluorescent staining was executed. EVs labeled with the red fluorescent membrane dye PKH26 were added to macrophages labeled with the green fluorescent dye PKH67. EV uptake was visualized by fluorescence microscopy (Figure 5). We observed EV internalization by macrophages at $2 \mathrm{~h}$ post-treatment.

The ability of EVs released from TOC to induce nitric oxide production in macrophage cell culture supernatants $48 \mathrm{~h}$ post-stimulation was evaluated (Figure 6). Macrophages were treated with two different doses of EVs only, or with EVs and LPS. For macrophages treated with EVs only, the high dose of EVs for all EV groups, except the EV AIV group, was able to induce a significant increase in NO production compared to the untreated control group. However, there was no significant difference between control group and low dose treatments. Furthermore, a significant difference between EV LPS, EV polyI:C, and EV CTRL low doses and high doses were observed within the respective groups. For the macrophages treated with EVs and $1 \mu \mathrm{g} / \mathrm{mL}$ LPS, a synergistic effect was observed for NO production in comparison to the $1 \mu \mathrm{g} / \mathrm{mL}$ LPS control group. For macrophages treated with EVs and LPS, the high dose of all groups was able to induce a significant increase in NO production compared to the LPS control group. In addition, for the EVs + LPS groups, a significant difference between the doses within each EV group was observed, with the 
low dose of EVs + LPS groups inducing a higher concentration nitrite of than the high dose of EVs + LPS groups.

PKH67
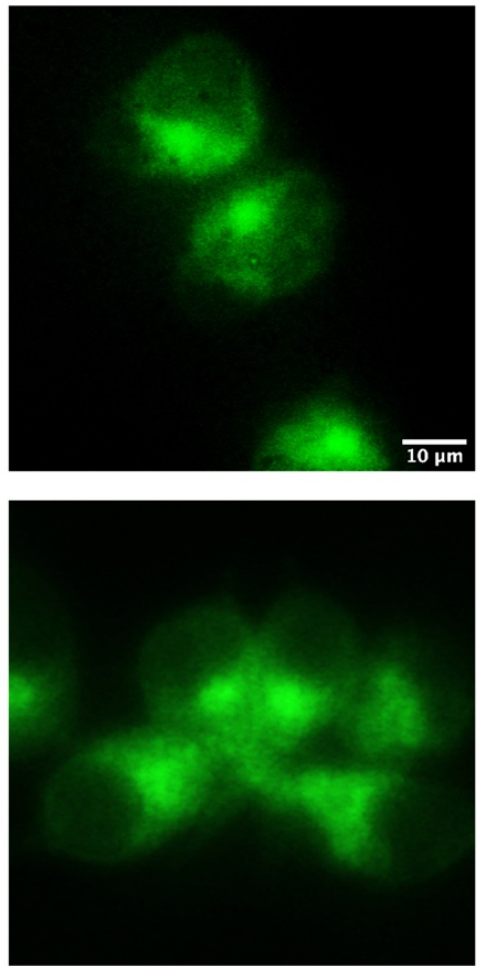

PKH26
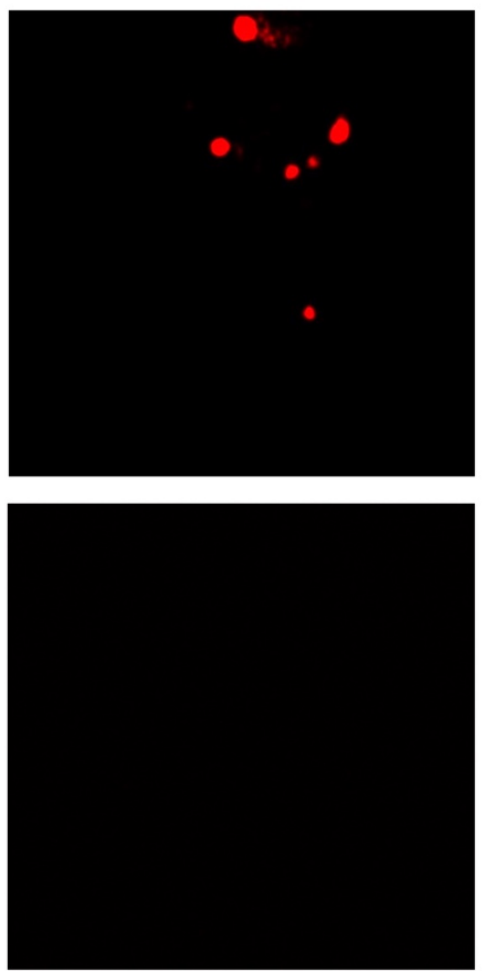

Merge
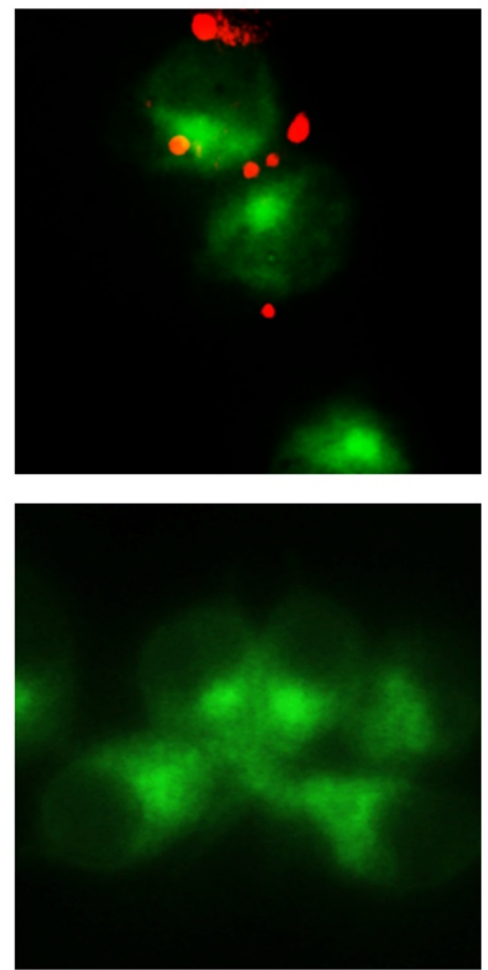

Figure 5. Uptake of EVs by chicken macrophage. PKH67-labelled (green) chicken macrophages were treated with $10 \mu \mathrm{g}$ of the PKH26-labelled (red) EVs and incubated at $40{ }^{\circ} \mathrm{C}$ and $50 \% \mathrm{CO}_{2}$ for $2 \mathrm{~h}$. The uptake of EVs by macrophages was detected by fluorescence microscopy.

Phagocytosis was then evaluated to investigate the effect of EV stimulation on macrophage functions. Phagocytosis was assessed by a fluorescent bead-based assay. Although there appears to be an increase in fluorescence intensity (relative fluorescence units, RFU) in all the EV groups compared to the untreated control, only the high dose of EV LPS group showed a significant increase in fluorescence intensity (Figure 7). Furthermore, no significant differences were observed between low and high doses within each EV group.

To assess the ability of EV treatment to influence the relative gene expression levels in chicken macrophages, macrophages were treated with a low dose $(5 \mu \mathrm{g} / \mathrm{mL})$ or a high dose $(25 \mu \mathrm{g} / \mathrm{mL})$ of EVs and collected at two different timepoints, $3 \mathrm{~h}$ and $18 \mathrm{~h}$ post-stimulation (Figure 8). The relative expression levels of IFN- $\alpha$, IFN- $\beta$, IL- $1 \beta$, PKR, and MDA5 were evaluated. We evaluated the relative gene expression levels of macrophages treated with EVs from chicken tracheal cells stimulated with AIV and LPS, as well as our EV CTRL group. Given the large amount of treatment groups from the different dosages and timepoints, we chose to exclude the EV polyI:C for this part of the experiment. The stimulation of macrophages with EV AIV, both low and high doses, as well as with a high dose of EV CTRL induced significant up-regulation of IFN- $\alpha$ at $3 \mathrm{~h}$ post-stimulation (Figure $8 \mathrm{a}$ ). Furthermore, there is an overall decrease in relative gene expression for both IFN- $\alpha$ and IFN- $\beta$ in all treatment groups at $18 \mathrm{~h}$ versus $3 \mathrm{~h}$ post-stimulation, with significant differences observed for the high dose of EV AIV for both IFN- $\alpha$ and IFN- $\beta$ and the low dose of EV LPS for IFN- $\alpha$ only (Figure $8 \mathrm{a}, \mathrm{b}$ ). All treatment groups for both timepoints showed significant upregulation of IL-1 $\beta$ (Figure $8 \mathrm{c}$ ). In addition, the upregulation of IL- $1 \beta$ for EV AIV and EV LPS groups is dose dependent. For PKR, there was no significant difference in relative gene expression at $3 \mathrm{~h}$ post-stimulation; however, there was significant downregulation for 
all of the EV groups at $18 \mathrm{~h}$ post-stimulation (Figure $8 \mathrm{~d}$ ). Similarly, there was no significant difference in relative gene expression at $3 \mathrm{~h}$ post-stimulation for MDA5 (Figure 8e). At $18 \mathrm{~h}$ post-stimulation, there was significant downregulation for all of the EV groups.

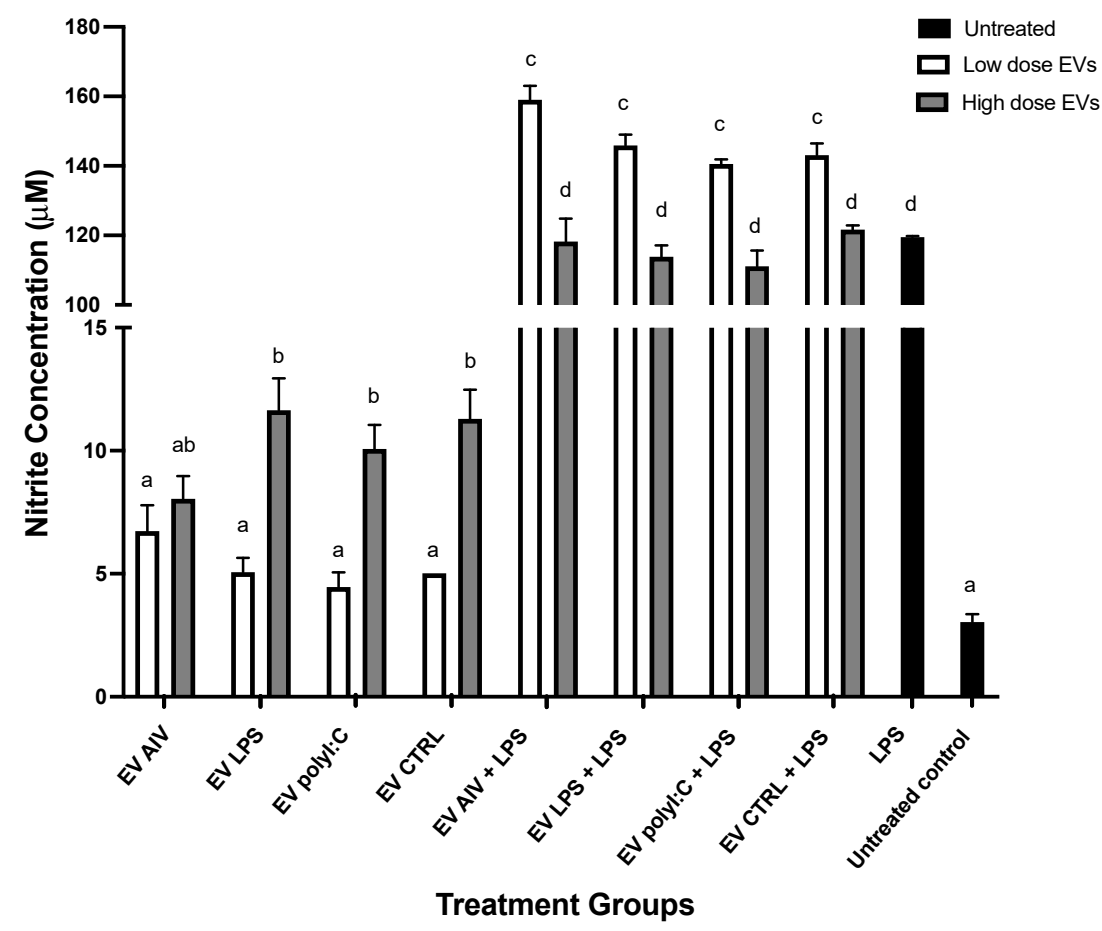

Figure 6. NO production by chicken macrophages stimulated with EVs. Macrophages were treated with either a low $(5 \mu \mathrm{g} / \mathrm{mL})$ or high $(50 \mu \mathrm{g} / \mathrm{mL})$ dose of EVs, with or without LPS treatment. NO production was assessed by the Griess assay. Significant differences ( $p$-value $<0.05$ ) are denoted by letters. Groups that are significantly different are represented by different letters. Groups with the same letters are not significantly different. The error bars represent the standard error of mean (SEM).

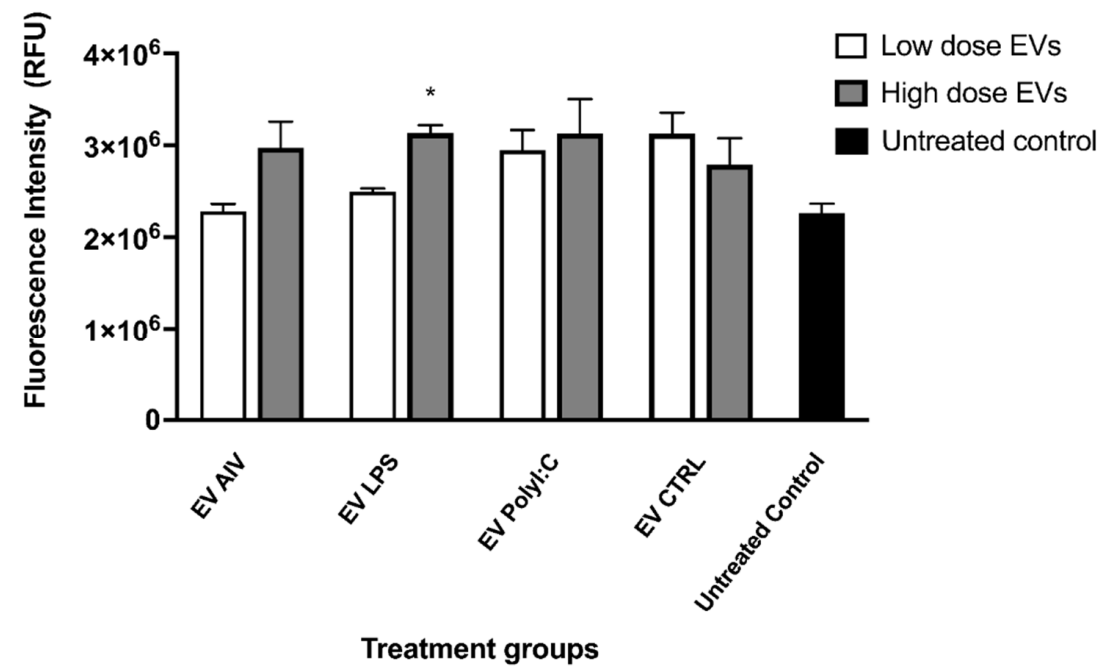

Figure 7. Phagocytosis by chicken macrophage stimulated with EVs. Two doses of EVs were used to treat macrophages, low $(5 \mu \mathrm{g} / \mathrm{mL})$ and high $(25 \mu \mathrm{g} / \mathrm{mL})$. Phagocytosis was assessed by a fluorescent bead-based assay using pHrodo Red Escherichia coli Bioparticles Conjugates. No significant differences in fluorescence intensity (relative fluorescence units, RFU) were observed as a result of EV treatment. Treatment groups with significant differences ( $p$-value $<0.05$ ) compared to the untreated control group are represented by *. The error bars represent the standard error of mean (SEM). 
IFN- $\boldsymbol{\alpha}$

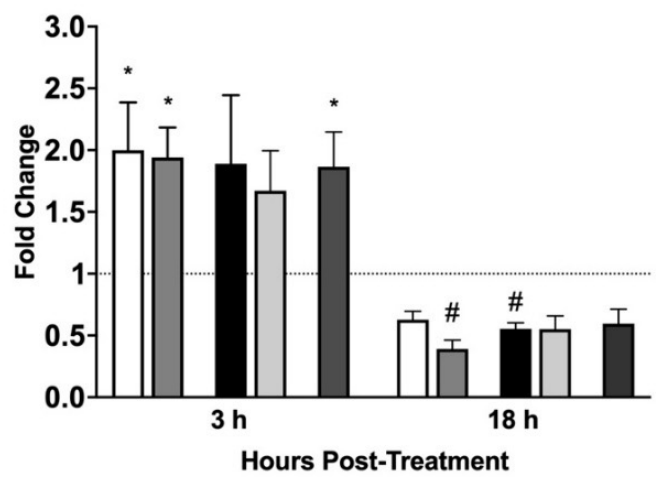

(a)

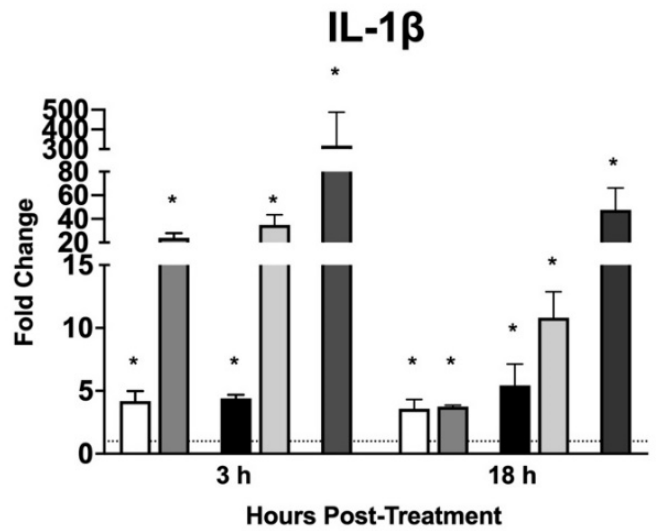

(c)
IFN- $\boldsymbol{\beta}$

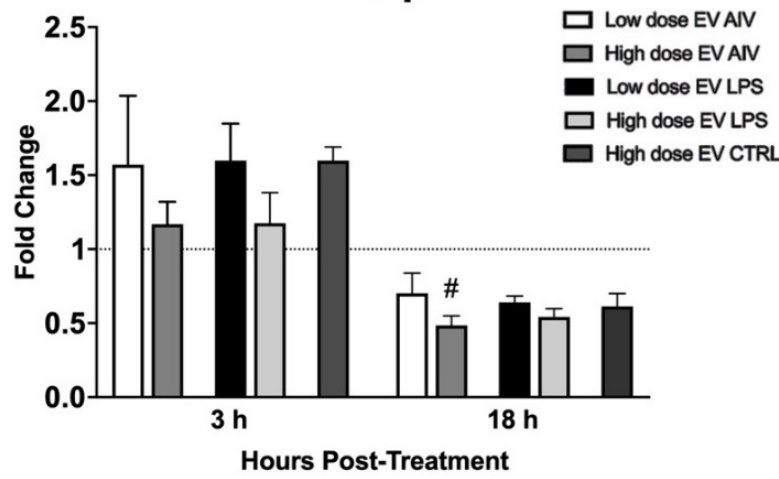

(b)

PKR

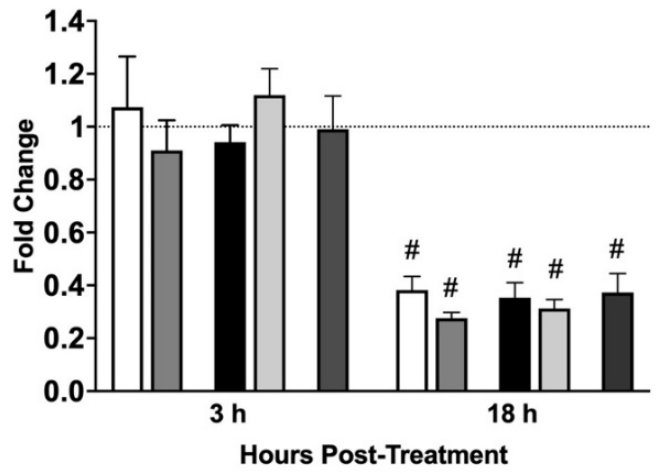

(d)

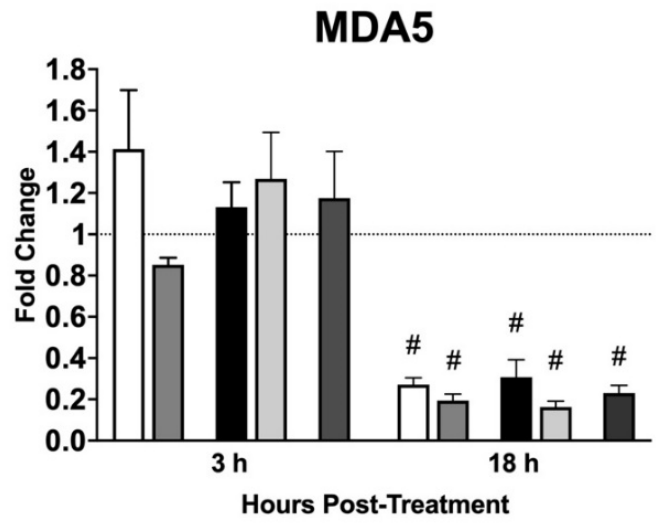

(e)

Figure 8. Relative gene expression of chicken macrophages stimulated with EVs. Macrophages were treated with a low dose $(5 \mu \mathrm{g} / \mathrm{mL})$ or a high dose $(25 \mu \mathrm{g} / \mathrm{mL})$ of EVs and collected at two different timepoints, $3 \mathrm{~h}$ and $18 \mathrm{~h}$ post-stimulation. The relative gene expression of IFN- $\alpha(\mathbf{a}), \operatorname{IFN}-\beta(\mathbf{b})$, IL-1 $\beta$ (c), PKR (d), and MDA5 (e) was measured by RT-qPCR. Treatment groups with significant up-regulation $(p$-value $<0.05)$ are represented by ${ }^{*}$, whereas treatment groups with significant downregulation $(p$-value $<0.05$ ) are represented by \#. The error bars represent the standard error of mean (SEM). 


\section{Discussion}

We previously described the induction and regulation of antiviral responses in tracheal cells and macrophages in the chicken respiratory system [29-32]. To further investigate the mechanisms by which this modulation occurs, we looked at the role of cellular and EV miRNAs in the context of antiviral responses in chicken tracheal cells. We showed the EV miRNA content can be influenced by AIV infection and TLR ligand stimulation [33]. Following this logic and knowing that EVs have an important protein content, we hypothesized that the proteomic profile is also influenced by AIV infection and TLR ligand stimulation of chicken tracheal cells. We first aimed to characterize the protein content of EVs after treatment. In this study, we have shown that EVs released from TOCs stimulated with AIV, LPS, or polyI:C have distinct proteomic profiles with key functions in cell signaling and immune responses.

During AIV infection or TLR ligand stimulation, the overall release of EVs is affected in terms of contents rather than the amount. In a previously published paper, it was demonstrated that the type of stimulation does not affect the amount of EVs released form cells. It was demonstrated that the type of stimuli can affect the miRNA contents of EVs [33]. First, we identified $140 \mathrm{DE}$ proteins in EVs released from chicken tracheal cells. We found 111 identified proteins in the ExoCarta and Vesiclepedia databases, whereas 29 proteins were not found in these EV proteome databases. Due to the heterogeneous nature of EVs across species and tissues, novel protein identification is expected [51]. More specifically, we characterized the proteome of EVs released from chicken tracheal cells for the first time; therefore, we expected to identify proteins previously found in EVs, but also proteins that are potentially specific to these types of respiratory EVs in chickens. Furthermore, we demonstrated that the proteomic profile of EVs released from chicken tracheal cells depends on the treatment (AIV, LPS, or polyI:C). This suggests that the EV protein content is influenced by viral infection or TLR ligand stimulation. This also expands and reinforces our conclusions drawn from the results of our previous study on miRNAs content in EVs released from chicken tracheal cells. Taken together, this supports the theory that EVs undergo specific cargo-loading and packaging [52]. Accumulating evidence has shown that EVs are master communicators during infection and may be reflected in EV contents $[53,54]$. In addition, some recent studies have shown that AIVs can be found in EVs and may play a role in the spread of the virus; however, no AIV proteins were detected in the EVs, suggesting that this strain of AIV is not packaged into EVs released from chicken tracheal cells as a means of viral dissemination [55]. This must be further validated by other methods such as viral RNA detection in EVs.

Venn diagram analysis provided insight into the commonalities and specific differences between our treatment groups. The 12 up-regulated proteins and 17 down-regulated proteins common to all the treatment groups may indicate similar roles in immunity or host-pathogen interactions as all the treatments that interact with the immune system. In contrast, the 9,17 , and 4 uniquely up-regulated proteins and 9, 22, and 20 uniquely downregulated proteins in the AIV, LPS, and polyI:C groups, respectively, suggest that these proteins may be reflective of specific signaling involved by the different stimulations. In addition, protein-protein interaction analysis revealed that proteins within these treatment groups are interconnected. As previously noted, several proteins were up-regulated in one group and down-regulated in another, further supporting the claim that the EV protein contents are highly dependent on the treatment. Uncovering the differences between the treatment groups allowed us to understand the differences in $\mathrm{EV}$ protein contents, but to gain a better understanding about the biological purposes of these proteins, we extracted gene ontology terms to predict the functions of the proteomic cargo. We must acknowledge the limitation of having a limited functionally annotated chicken protein database and have integrated the use of the human gene symbols for our functional analysis. This type of analysis is a first step towards deciphering the EV proteins' specific functions. We found that the terms associated with the proteins in the EVs were greatly varied. We were interested in terms associated with cell signaling and immune responses. 
For example, the protein EOMES (R4GH67) was down-regulated in all treatment groups and associated with the biological process term "immune system process". EOMES (R4GH67) or Eomesodermin is a T-box transcription factor involved in the early developmental process of mesoderm specification during gastrulation [56]. This protein also has roles in the functions of effector and memory $\mathrm{T}$ cells, and high levels of Eomesodermin have been associated with CD8+ T cell exhaustion [57,58]. CD8+ T cells are essential for protective immunity against intracellular pathogens, but during chronic infections, constant exposure to antigen or inflammatory signals leads to the deterioration of $\mathrm{T}$ cell function [59]. A possible explanation for down-regulation of EOMES (R4GH67) in all treatment groups is a negative regulation to prevent $\mathrm{CD} 8+\mathrm{T}$ cell exhaustion upon activation of the immune system. Another example is the protein associated with the inflammation mediated by chemokine and cytokine signaling pathways, PLCE1 (A0A1D5PQ57) or Phospholipase C epsilon 1 (down-regulated in the AIV and polyI:C groups) and RGS14 (A0A1D5PPP1). A study in esophageal squamous cell carcinoma showed that inflammation or immunerelated TLR4, IL-8, IL-6, and chemokine (C-X-C motif) ligand 2 (CXCL2) were increased upon PLCE1 suppression [60]. This suggests that the downregulation of PLCE1 in the AIV and polyI:C groups may serve to have an upregulation of these the goal is to have an upregulation of these immune immune-related molecules. Finally, up-regulated proteins COL4A1 (A0A1D5P8P3) and COL27A1 (F1NHH4) and down-regulated protein COL1A2 (A0A5H1ZRJ7) from the LPS group were found to be associated with the integrin signaling pathways. EVs express integrins on their surfaces and serve many purposes, such as communication by guiding EVs to specific tissues or cells [61]. Collagens (COL) are members of the integrin family and protein support to different tissues, but also regulate cell growth and differentiation [62]. The presence of several differentially regulated collagen proteins within EVs highlights the fine-tuned regulation of processes and cargo-loading of specific proteins. These associated terms recapitulate the nature of EVs in the immune response and cell signaling.

EVs can impact the immune response in a variety of different ways, such as through the NF- $\mathrm{KB}$ signaling pathway $[27,28]$. Chicken tracheal epithelial cells mount antiviral responses through similar pathways [32]. These types of signaling pathways require highly regulated communication between cells, highlighting a potential role for EVs as intercellular mediators. AIV infection or TLR ligand stimulation leads to important immunological changes in chicken tracheal cells. Specifically, there is induction in the expression of proinflammatory cytokines, interferons, and interferon-stimulated genes [32]. EVs released from tracheal cells also undergo important changes in content under similar stimulation conditions. The presence of proteins involved in immune responses and cell signaling in these EVs indicates a potential correlation between cellular and reflected EV changes. Although this study provides an important overview of the contents of EVs released from chicken tracheal cells under different conditions, i.e., AIV infection, timing is of extreme importance in the context of antiviral responses, and so a key limitation of this study is that it does not evaluate the change in released EV content over time. Investigation into these changes would be complementary to the results presented in this study, as there may be important changes at different time points post-stimulation. Furthermore, although knowledge about these specific EV proteins within provides insight into their potential roles, the specific functions in the context of EVs and the antiviral response would need to be further validated with functional studies evaluating individual proteins.

Knowing that the EVs contained proteins important in immune response and cell signaling, the second aim of this study was to evaluate the potential impact or specific roles that EVs have on macrophage functions or the potential roles in communication. We chose to evaluate the impact of EVs on macrophage function because we previously demonstrated the communication and interaction between chicken tracheal cells and chicken macrophages in the context of antiviral responses [29-32]. We hypothesized that EVs may play a role here. We demonstrated that EVs released from TOCs impact macrophage function. We first demonstrated that chicken macrophages can uptake EVs rather than simply sense them. 
Many cells have been shown to uptake EVs, including macrophages [45]. EV populations can be very heterogenous, especially among different species and cell and tissue types, resulting in a variety of potential routes for sensing or uptake [63,64]. In order to determine the exact mechanism for EV uptake, such as endocytosis or phagocytosis, further studies are required. Furthermore, certain specific proteins are required for certain receptor-mediated internalization mechanisms; therefore, a cross-reference to the identified EV proteins would be required.

Following EV uptake, we investigated macrophage activation through evaluation of NO production. NO production in macrophages was evaluated as it is an indicator of macrophage activation $[65,66]$. In addition, LPS was used as a positive control of macrophage activation as it was previously shown to induce NO production in chicken macrophages [29]. EVs alone (high dose of EV LPS, EV polyI:C, and EV CTRL) were able to induce significant increases in NO production compared to the untreated group, indicating the ability to activate macrophages. Furthermore, we observed a synergistic effect in the EV + LPS groups, with the low dose of EVs inducing a higher amount of NO. This showed that EVs were able to boost the LPS activation of macrophages. This may be due to the existence of negative feedback loops in the NO production pathway [67]. No notable comparisons between EV groups were observed, indicating that the induction of NO production may be due to the presence of EVs themselves and not particularly the EV contents, which we showed to be distinct among the treatment groups. Upon investigating the ability of EV stimulation to impact the phagocytic abilities of macrophages, as phagocytosis is an important function of activated avian macrophages, we found that the only the high dose of EV LPS had a significant impact on phagocytosis compared to the untreated control group [5]. Knowing that LPS is a potent activator of chicken macrophages, these phagocytosis data suggest that EVs may contain specific molecules and components of signaling pathways, which may act in transferring the activation "message" induced by LPS stimulation [29]. Further investigation is needed to determine the exact molecular mechanisms.

The coordination of antiviral responses is mediated through signaling pathways involving many components. Increased relative gene expression of IFN- $\alpha$ for some EV groups at $3 \mathrm{~h}$ post-stimulation indicates an early activation of the IFN pathways, which is crucial in the antiviral response [68]. At $18 \mathrm{~h}$ post-stimulation, the change in relative expression for both IFN- $\alpha$ and IFN- $\beta$ is significantly down-regulated for some groups and insignificant for others. This may indicate that the IFN expression is more important at the initial stages of macrophage stimulation. IL- $1 \beta$, an important mediator of the inflammatory response, was significantly up-regulated for all the groups and the relative gene expression was dose dependent. More specifically, the high dose of EVs inducing higher levels of IL-1 $\beta$ than the low dose of EVs. Furthermore, IL-1 $\beta$ can initiate NO synthesis; therefore, the induced NO production we observed in the macrophages may be due to the EVs themselves or by the increased levels of IL-1 $\beta$ [69]. Finally, both the ISGs RNA-activated protein kinase $R$ (PKR) and melanoma differentiation-associated gene 5 (MDA5) are significantly downregulated in some EV groups at $18 \mathrm{~h}$ post-stimulation. This may indicate a less important role for these molecules at $18 \mathrm{~h}$ versus $3 \mathrm{~h}$ post-stimulation [70,71]. Taken together, NO production, phagocytosis, and gene expression data for macrophages support the notion that responses to viral infections are complex and, more likely than not, it is a combination or network of proteins and other EV contents that play a role in the induction of the antiviral state and the impact on other cells.

\section{Conclusions}

In conclusion, we investigated the overall protein profile of EVs released from chicken tracheal cells in response to AIV infection and TLR ligand stimulation. We showed that EV contents are influenced by the treatment received by the chicken tracheal cells and that these EVs are enriched in proteins involved in immune responses and cell signaling. Furthermore, we evaluated the impact of EV stimulation on other cells of the immune system and 
showed that EVs have the ability to activate macrophages. Additional functional studies are required to elucidate the mechanisms responsible for selective EV cargo loading and for the impact of EV stimulation on the antiviral activity and activation of macrophages. Although further functional studies are required to validate specific EV protein functions, this study revealed the role of respiratory EVs in the induction and modulation of antiviral responses against viral infections. A greater understanding of EV contents and functions will ultimately lead to the development of specifically tailored EV therapeutics applicable in the context of infectious viral disease.

Supplementary Materials: The following are available online at https:/ /www.mdpi.com/article/10 .3390/membranes12010053/s1, Table S1. DE proteins found in ExoCarta and Vesiclepedia databases; Table S2. Intersecting sets of up-regulated proteins of EVs from TOCs treated with AIV, LPS, and polyI:C; Table S3. PANTHER gene set enrichment analysis of DE proteins; Table S4. PANTHER pathway analysis; Figure S1. Network analysis of protein-protein interactions among AIV upregulated (a), AIV down-regulated (b), LPS up-regulated (c), LPS down-regulated (d), polyI:C up-regulated (e), and polyI:C down-regulated (f) groups of EVs from TOCs, obtained from STRING database, where blue edges represent known interactions from curated databases, purple edges represent experimentally determined known interactions, yellow edges represent interactions from textmining, and black edges represent interactions from co-expression.

Author Contributions: Conceptualization, N.B. and K.O.; methodology, N.B. and F.B.; software, F.B.; validation, N.B.; formal analysis, N.B., F.B. and K.O.; investigation, N.B., F.B., K.O., L.S. and J.B.S.; resources, N.B. and F.B.; data curation, F.B.; writing-original draft preparation, N.B. and K.O.; writing-review and editing, N.B., F.B. and K.O.; visualization, K.O.; supervision, N.B.; project administration, N.B.; funding acquisition, N.B. All authors have read and agreed to the published version of the manuscript.

Funding: This research was funded by the Quebec Respiratory Health Research Network (QRHN) grant number 00222, and J. L. Lévesque Foundation grant number R103. Kelsey O’Dowd was a recipient of a scholarship from the Swine and Poultry Infectious Diseases Research Centre (CRIPA), a research network financially supported by the Fonds de recherche du Québec-Nature et technologies (FRQNT). The article processing charge (APC) was funded by J. L. Lévesque Foundation grant number R103. MS equipment was funded by the Canadian Foundation for Innovation (CFI) and the Fonds de Recherche du Québec (FRQ), the Government of Quebec (F. Beaudry CFI John R. Evans Leaders grant number 36706). Ph.D. scholarships were awarded to J. Ben Salem from the Fonds de Recherche du Québec-Santé.

Institutional Review Board Statement: This study was conducted in compliance with the guidelines of the Canadian Council on Animal Care including animal care, procedures, and program management. The study was conducted according to the guidelines of Animal Care Committee of the Université de Montréal. Specific pathogen-free (SPF) eggs were purchased from the Animal Disease Research Institute, Canadian Food, Inspection Agency (Ottawa, ON, Canada). In this study, SPF 10-day-old embryonated chicken eggs were inoculated with H4N6 AIV.

Data Availability Statement: Data are contained within the article or Supplementary Materials.

Acknowledgments: Funding for this work was provided by the Quebec Respiratory Health Research Network (QRHN), J.L Lévesque Foundation and the Université de Montréal. Kelsey O'Dowd was a recipient of a scholarship from the Swine and Poultry Infectious Disease Research Center (CRIPA), a research network financially supported by the Fonds de recherche du Québec-Nature et technologies (FRQNT).

Conflicts of Interest: The authors declare no conflict of interest. The funders had no role in the design of the study; in the collection, analyses, or interpretation of data; in the writing of the manuscript, or in the decision to publish the results.

\section{References}

1. Miura, T.A. Respiratory Epithelial Cells as Master Communicators during Viral Infections. Curr. Clin. Microbiol. Rep. 2019, 6, 10-17. [CrossRef]

2. Yan, N.; Chen, Z.J. Intrinsic antiviral immunity. Nat. Immunol. 2012, 13, 214-222. [CrossRef] 
3. McNab, F.; Mayer-Barber, K.; Sher, A.; Wack, A.; O'Garra, A. Type I interferons in infectious disease. Nat. Rev. Immunol. 2015, 15, 87-103. [CrossRef] [PubMed]

4. Rivera, A.; Siracusa, M.C.; Yap, G.S.; Gause, W.C. Innate cell communication kick-starts pathogen-specific immunity. Nat. Immunol. 2016, 17, 356-363. [CrossRef]

5. Qureshi, M.A.; Heggen, C.L.; Hussain, I. Avian macrophage: Effector functions in health and disease. Dev. Comp. Immunol. 2000, 24, 103-119. [CrossRef]

6. Dreux, M.; Garaigorta, U.; Boyd, B.; Décembre, E.; Chung, J.; Whitten-Bauer, C.; Wieland, S.; Chisari, F.V. Short-Range Exosomal Transfer of Viral RNA from Infected Cells to Plasmacytoid Dendritic Cells Triggers Innate Immunity. Cell Host Microbe 2012, 12, 558-570. [CrossRef]

7. Brennan, K. A comparison of methods for the isolation and separation of extracellular vesicles from protein and lipid particles in human serum. Sci. Rep. 2020, 10, 1039.

8. Yáñez-Mó, M.; Borràs, F.E.; Buzas, E.I.; Buzas, K.; Casal, E.; Cappello, F.; Carvalho, J.; Colás, E.; Cordeiro-da, A.; Fais, S.; et al. Biological properties of extracellular vesicles and their physiological functions. J. Extracell. Vesicles 2015, 4, 27066. [CrossRef] [PubMed]

9. Lötvall, J.; Hill, A.F.; Hochberg, F.; Buzás, E.I.; Vizio, D.D.; Gardiner, C.; Gho, Y.S.; Kurochkin, I.V.; Mathivanan, S.; Quesenberry, P.; et al. Minimal experimental requirements for definition of extracellular vesicles and their functions: A position statement from the International Society for Extracellular Vesicles. J. Extracell. Vesicles 2014, 3, 26913. [CrossRef] [PubMed]

10. Toribio, V.; Morales, S.; López-Martín, S.; Cardeñes, B.; Cabañas, C.; Yáñez-Mó, M. Development of a quantitative method to measure EV uptake. Sci. Rep. 2019, 9, 10522. [CrossRef] [PubMed]

11. Valadi, H.; Ekström, K.; Bossios, A.; Sjöstrand, M.; Lee, J.J.; Lötvall, J.O. Exosome-mediated transfer of mRNAs and microRNAs is a novel mechanism of genetic exchange between cells. Nat. Cell Biol. 2007, 9, 654-659. [CrossRef] [PubMed]

12. Quaglia, M.; Dellepiane, S.; Guglielmetti, G.; Merlotti, G.; Castellano, G.; Cantaluppi, V. Extracellular Vesicles as Mediators of Cellular Crosstalk Between Immune System and Kidney Graft. Front. Immunol. 2020, 11, 74. [CrossRef] [PubMed]

13. Felekkis, K.; Touvana, E.; Stefanou, C.; Deltas, C. MicroRNAs: A newly described class of encoded molecules that play a role in health and disease. Hippokratia 2010, 14, 236-240.

14. Chahar, H.S.; Corsello, T.; Kudlicki, A.S.; Komaravelli, N.; Casola, A. Respiratory Syncytial Virus Infection Changes Cargo Composition of Exosome Released from Airway Epithelial Cells. Sci. Rep. 2018, 8, 387. [CrossRef]

15. Chettimada, S.; Lorenz, D.R.; Misra, V.; Dillon, S.T.; Reeves, R.K.; Manickam, C.; Morgello, S.; Kirk, G.D.; Mehta, S.H.; Gabuzda, D. Exosome markers associated with immune activation and oxidative stress in HIV patients on antiretroviral therapy. Sci. Rep. 2018, 8, 7227. [CrossRef]

16. Bello-Morales, R. Extracellular Vesicles in Viral Spread and Antiviral Response. Viruses 2020, 12, 623. [CrossRef]

17. Petrik, J. Immunomodulatory effects of exosomes produced by virus-infected cells. Transfus. Apher. Sci. 2016, 55, 84-91. [CrossRef] [PubMed]

18. Yao, Z.; Qiao, Y.; Li, X.; Chen, J.; Ding, J.; Bai, L.; Shen, F.; Shi, B.; Liu, J.; Peng, L.; et al. Exosomes Exploit the Virus Entry Machinery and Pathway To Transmit Alpha Interferon-Induced Antiviral Activity. J. Virol. 2018, 92, e01578-18. [CrossRef]

19. Hong, Y.; Truong, A.D.; Lee, J.; Vu, T.H.; Lee, S.; Song, K.D.; Lillehoj, H.S.; Hong, Y.H. Exosomal miRNA profiling from H5N1 avian influenza virus-infected chickens. Vet. Res. 2021, 52, 36. [CrossRef]

20. del Cacho, E.; Gallego, M.; Lee, S.H.; Lillehoj, H.S.; Quilez, J.; Lillehoj, E.P.; Sánchez-Acedo, C. Induction of Protective Immunity against Eimeria tenella, Eimeria maxima, and Eimeria acervulina Infections Using Dendritic Cell-Derived Exosomes. Infect. Immun. 2012, 80, 1909-1916. [CrossRef]

21. del Cacho, E.; Gallego, M.; Lillehoj, H.S.; Quilez, J.; Lillehoj, E.P.; Sánchez-Acedo, C. Induction of protective immunity against experimental Eimeria tenella infection using serum exosomes. Vet. Parasitol. 2016, 224, 36. [CrossRef] [PubMed]

22. Zhao, Y.; Fu, Y.; Zou, M.; Sun, Y.; Yin, X.; Niu, L.; Peng, X. Analysis of deep sequencing Exosome-microRNA expression profile from Chicken Type II Pneumocytes derived reveals potential role of gga-miRNA-451 in inflammation. J. Cell. Mol. Med. 2020, 24, 6178-6190. [CrossRef] [PubMed]

23. Wang, Y.; Wang, G.; Wang, Z.; Zhang, H.; Zhang, L.; Cheng, Z. Chicken biliary exosomes enhance CD4+T proliferation and inhibit ALV-J replication in liver. Biochem. Cell Biol. 2014, 92, 145-151. [CrossRef] [PubMed]

24. Neerukonda, S.N.; Tavlarides-Hontz, P.; McCarthy, F.; Pendarvis, K.; Parcells, M.S. Comparison of the Transcriptomes and Proteomes of Serum Exosomes from Marek's Disease Virus-Vaccinated and Protected and Lymphoma-Bearing Chickens. Genes 2019, 10, 116. [CrossRef] [PubMed]

25. Li, L.; Zhuang, P.; Cheng, Z.; Yang, J.; Bi, J.; Wang, G. Avian leukosis virus subgroup J and reticuloendotheliosis virus coinfection induced TRIM62 regulation of the actin cytoskeleton. J. Vet. Sci. 2020, 21, e49. [CrossRef]

26. Ye, F.; Wang, Y.; He, Q.; Cui, C.; Yu, H.; Lu, Y.; Zhu, S.; Xu, H.; Zhao, X.; Yin, H.; et al. Exosomes transmit viral genetic information and immune signals may cause immunosuppression and immune tolerance in ALV-J infected hd11 cells. Int. J. Biol. Sci. 2020, 16, 904-920. [CrossRef]

27. Hong, Y.; Lee, J.; Vu, T.H.; Lee, S.; Lillehoj, H.S.; Hong, Y.H. Exosomes of lipopolysaccharide-stimulated chicken macrophages modulate immune response through the MyD88/NF-kB signaling pathway. Dev. Comp. Immunol. 2021, 115, 103908. [CrossRef] [PubMed] 
28. Hong, Y.; Lee, J.; Vu, T.H.; Lee, S.; Lillehoj, H.S.; Hong, Y.H. Immunomodulatory effects of poly(I:C)-stimulated exosomes derived from chicken macrophages. Poult. Sci. 2021, 100, 101247. [CrossRef]

29. Barjesteh, N.; Behboudi, S.; Brisbin, J.T.; Villanueva, A.I.; Nagy, É.; Sharif, S. TLR ligands induce antiviral responses in chicken macrophages. PLoS ONE 2014, 9, e105713. [CrossRef]

30. Barjesteh, N.; Shojadoost, B.; Brisbin, J.T.; Emam, M.; Hodgins, D.C.; Nagy, É.; Sharif, S. Reduction of avian influenza virus shedding by administration of Toll-like receptor ligands to chickens. Vaccine 2015, 33, 4843-4849. [CrossRef]

31. Barjesteh, N.; Alkie, T.N.; Hodgins, D.C.; Nagy, É; Sharif, S. Local innate responses to TLR ligands in the chicken trachea. Viruses 2016, 8, 207. [CrossRef]

32. Barjesteh, N.; Taha-Abdelaziz, K.; Kulkarni, R.R.; Sharif, S. Innate antiviral responses are induced by TLR3 and TLR4 ligands in chicken tracheal epithelial cells: Communication between epithelial cells and macrophages. Virology 2019, 534, 132-142. [CrossRef]

33. O’Dowd, K.; Emam, M.; El Khili, M.R.; Emad, A.; Ibeagha-Awemu, E.M.; Gagnon, C.A.; Barjesteh, N. Distinct miRNA Profile of Cellular and Extracellular Vesicles Released from Chicken Tracheal Cells Following Avian Influenza Virus Infection. Vaccines 2020, 8, 438. [CrossRef] [PubMed]

34. Szretter, K.J.; Balish, A.L.; Katz, J.M. Influenza: Propagation, quantification, and storage. Curr. Protoc. Microbiol. 2006, 3 , 15G-1. [CrossRef] [PubMed]

35. Webster, R.; Cox, N.; Stohr, K. WHO Manual on Animal Influenza Diagnosis and Surveillance: World Health Organization, Department of Communicable Disease Surveillance and Response. WHO/CDS/CDR/2002.5. World Health Organ. 2002, 1, 48-54.

36. Qureshi, M.A.; Miller, L.; Lillehoj, H.S.; Ficken, M.D. Establishment and characterization of a chicken mononuclear cell line. Vet. Immunol. Immunopathol. 1990, 26, 237-250. [CrossRef]

37. Hossain, M.J.; Mori, I.; Dong, L.; Liu, B.; Kimura, Y. Fetal calf serum inhibits virus genome expression in Madin-Darby canine kidney cells persistently infected with influenza A virus. Med. Microbiol. Immunol. 2008, 197, 21-27. [CrossRef] [PubMed]

38. The, M.; MacCoss, M.J.; Noble, W.S.; Käll, L. Fast and Accurate Protein False Discovery Rates on Large-Scale Proteomics Data Sets with Percolator 3.0. J. Am. Soc. Mass Spectrom. 2016, 27, 1719-1727. [CrossRef] [PubMed]

39. Orsburn, B.C. Proteome discoverer-a community enhanced data processing suite for protein informatics. Proteomes $2021,9,15$. [CrossRef]

40. Keerthikumar, S.; Chisanga, D.; Ariyaratne, D.; Al Saffar, H.; Anand, S.; Zhao, K.; Samuel, M.; Pathan, M.; Jois, M.; Chilamkurti, N.; et al. ExoCarta: A Web-Based Compendium of Exosomal Cargo. J. Mol. Biol. 2016, 428, 688-692. [CrossRef]

41. Pathan, M.; Fonseka, P.; Chitti, S.V.; Kang, T.; Sanwlani, R.; Van Deun, J.; Hendrix, A.; Mathivanan, S. Vesiclepedia 2019: A compendium of RNA, proteins, lipids and metabolites in extracellular vesicles. Nucleic Acids Res. 2019, 47, D516-D519. [CrossRef] [PubMed]

42. Mi, H.; Muruganujan, A.; Ebert, D.; Huang, X.; Thomas, P.D. PANTHER version 14: More genomes, a new PANTHER GO-slim and improvements in enrichment analysis tools. Nucleic Acids Res. 2019, 47, D419-D426. [CrossRef] [PubMed]

43. Shannon, P.; Markiel, A.; Ozier, O.; Baliga, N.S.; Wang, J.T.; Ramage, D.; Amin, N.; Schwikowski, B.; Ideker, T. Cytoscape: A software environment for integrated models of biomolecular interaction networks. Genome Res. 2003, 13, 2498-2504. [CrossRef] [PubMed]

44. Szklarczyk, D.; Gable, A.L.; Lyon, D.; Junge, A.; Wyder, S.; Huerta-Cepas, J.; Simonovic, M.; Doncheva, N.T.; Morris, J.H.; Bork, P.; et al. STRING v11: Protein-protein association networks with increased coverage, supporting functional discovery in genome-wide experimental datasets. Nucleic Acids Res. 2019, 47, D607-D613. [CrossRef] [PubMed]

45. Lässer, C.; Seyed Alikhani, V.; Ekström, K.; Eldh, M.; Torregrosa Paredes, P.; Bossios, A.; Sjöstrand, M.; Gabrielsson, S.; Lötvall, J.; Valadi, H. Human saliva, plasma and breast milk exosomes contain RNA: Uptake by macrophages. J. Transl. Med. 2011, 9, 9. [CrossRef] [PubMed]

46. Schindelin, J.; Arganda-Carreras, I.; Frise, E.; Kaynig, V.; Longair, M.; Pietzsch, T.; Preibisch, S.; Rueden, C.; Saalfeld, S.; Schmid, B.; et al. Fiji: An open-source platform for biological-image analysis. Nat. Methods 2012, 9, 676-682. [CrossRef]

47. Preibisch, S.; Saalfeld, S.; Tomancak, P. Globally optimal stitching of tiled 3D microscopic image acquisitions. Bioinformatics 2009, 25, 1463-1465. [CrossRef]

48. Pfaffl, M.W. A new mathematical model for relative quantification in real-time RT-PCR. Nucleic Acids Res. 2001, 29, e45. [CrossRef]

49. St Paul, M.; Mallick, A.I.; Haq, K.; Orouji, S.; Abdul-Careem, M.F.; Sharif, S. In vivo administration of ligands for chicken toll-like receptors 4 and 21 induces the expression of immune system genes in the spleen. Vet. Immunol. Immunopathol. 2011, 144, $228-237$. [CrossRef]

50. Villanueva, A.I.; Kulkarni, R.R.; Sharif, S. Synthetic double-stranded RNA oligonucleotides are immunostimulatory for chicken spleen cells. Dev. Comp. Immunol. 2011, 35, 28-34. [CrossRef]

51. Raposo, G.; Stahl, P.D. Extracellular vesicles: A new communication paradigm? Nat. Rev. Mol. Cell Biol. 2019, 20, 509-510. [CrossRef] [PubMed]

52. Margolis, L.; Sadovsky, Y. The biology of extracellular vesicles: The known unknowns. PLoS Biol. 2019, 17, e3000363. [CrossRef] [PubMed]

53. White, J.R.; Dauros-Singorenko, P.; Hong, J.; Vanholsbeeck, F.; Phillips, A.; Swift, S. The complex, bidirectional role of extracellular vesicles in infection. Biochem. Soc. Trans. 2021, 49, 881-891. [CrossRef] 
54. Gupta, R.; Radicioni, G.; Abdelwahab, S.; Dang, H.; Carpenter, J.; Chua, M.; Mieczkowski, P.A.; Sheridan, J.T.; Randell, S.H.; Kesimer, M. Intercellular communication between airway epithelial cells is mediated by exosome-like vesicles. Am. J. Respir. Cell Mol. Biol. 2019, 60, 209-220. [CrossRef]

55. Jiang, Y.; Cai, X.; Yao, J.; Guo, H.; Yin, L.; Leung, W.; Xu, C. Role of Extracellular Vesicles in Influenza Virus Infection. Front. Cell. Infect. Microbiol. 2020, 10, 366. [CrossRef] [PubMed]

56. Dorshorst, B.; Harun-Or-Rashid, M.; Bagherpoor, A.J.; Rubin, C.J.; Ashwell, C.; Gourichon, D.; Tixier-Boichard, M.; Hallböök, F.; Andersson, L. A Genomic Duplication is Associated with Ectopic Eomesodermin Expression in the Embryonic Chicken Comb and Two Duplex-comb Phenotypes. PLoS Genet. 2015, 11, e1004947. [CrossRef]

57. Li, J.; He, Y.; Hao, J.; Ni, L.; Dong, C. High Levels of Eomes Promote Exhaustion of Anti-tumor CD8+ T Cells. Front. Immunol. 2018, 9, 2981. [CrossRef]

58. Pearce, E.L.; Mullen, A.C.; Martins, G.A.; Krawczyk, C.M.; Hutchins, A.S.; Zediak, V.P.; Banica, M.; DiCioccio, C.B.; Gross, D.A.; Mao, C.A.; et al. Control of Effector CD8+ T Cell Function by the Transcription Factor Eomesodermin. Science 2003, 302, 1041-1043. [CrossRef]

59. Kurachi, M. CD8 + T cell exhaustion. Semin. Immunopathol. 2019, 41, 327-337. [CrossRef]

60. Cui, X.; Xin, H.; Peng, H.; Chen, Y. Comprehensive bioinformatics analysis of the mRNA profile of PLCE1 knockdown in esophageal squamous cell carcinoma. Mol. Med. Rep. 2017, 16, 5871-5880. [CrossRef]

61. Shimaoka, M.; Kawamoto, E.; Gaowa, A.; Okamoto, T.; Park, E.J. Connexins and integrins in exosomes. Cancers 2019, 11, 106. [CrossRef] [PubMed]

62. Albacete-Albacete, L. Extracellular Vesicles: An Emerging Mechanism Governing the Secretion and Biological Roles of Tenascin-C. Front. Immunol. 2021, 12, 671485. [CrossRef] [PubMed]

63. Mulcahy, L.A.; Pink, R.C.; Carter, D.R.F. Routes and mechanisms of extracellular vesicle uptake. J. Extracell. Vesicles 2014,3 , 24641. [CrossRef]

64. Koliha, N. Analysis of the microRNA profile and origin of exosomes in plasma of melanoma patients and healthy individuals. Friedrich-Alexander-Univ. Erlangen-Nürnb. 2016, 115, 6779-6789.

65. Li, Y.H.; Yan, Z.Q.; Brauner, A.; Tullus, K. Activation of macrophage nuclear factor- $\mathrm{kB}$ and induct ion of inducible nitric oxide synthase by LPS. Respir. Res. 2002, 3, 23. [CrossRef] [PubMed]

66. Mosser, D.M.; Edwards, J.P. Exploring the full spectrum of macrophage activation David. Nat. Rev. Immunol. 2009, 8, 958-969. [CrossRef]

67. Kopincová, J.; Púzserová, A.; Bernátová, I. Biochemical aspects of nitric oxide synthase feedback regulation by nitric oxide. Interdiscip. Toxicol. 2011, 4, 63-68. [CrossRef] [PubMed]

68. Santhakumar, D.; Rubbenstroth, D.; Martinez-Sobrido, L.; Munir, M. Avian interferons and their antiviral effectors. Front. Immunol. 2017, 8, 49. [CrossRef]

69. Kwon, S.; Newcomb, R.L.; George, S.C. Mechanisms of synergistic cytokine-induced nitric oxide production in human alveolar epithelial cells. Nitric Oxide 2001, 5, 534-546. [CrossRef]

70. Dauber, B.; Wolff, T. Activation of the antiviral kinase PKR and viral countermeasures. Viruses 2009, 1, 523-544. [CrossRef]

71. Dias Junior, A.G.; Sampaio, N.G.; Rehwinkel, J. A Balancing Act: MDA5 in Antiviral Immunity and Autoinflammation. Trends Microbiol. 2019, 27, 75-85. [CrossRef] [PubMed] 